\title{
Changes in species composition of Haploniscidae (Crustacea: Isopoda) across potential barriers to dispersal in the Northwest Pacific
}

\author{
Nele Johannsen $^{\mathrm{a}, \mathrm{b}}$, Lidia Lins ${ }^{\mathrm{a}, \mathrm{b}, \mathrm{c}}$, Torben Riehl ${ }^{\mathrm{a}, \mathrm{b}}$, Angelika Brandt ${ }^{\mathrm{a}, \mathrm{b}, *}$ \\ ${ }^{a}$ Goethe University, Biosciences, Institute for Ecology, Evolution und Diversity, Max-von-Laue-Str. 13, 60438 Frankfurt am Main, Germany \\ ${ }^{\mathrm{b}}$ Senckenberg Research Institute and Natural History Museum, Marine Zoology, Senckenberganlage 25, 60325 Frankfurt am Main, Germany

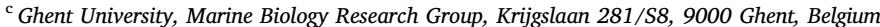

\section{A R T I C L E I N F O}

\section{Keywords:}

Hadal

Ecology

Sea of Okhotsk

Deep sea

Abyssal

Isopoda

Kuril Kamchatka Trench

Distribution

Northwest Pacific

Systematics

\begin{abstract}
A B S T R A C T
Speciation processes as drivers of biodiversity in the deep sea are still not fully understood. One potential driver for species diversification might be allopatry caused by geographical barriers, such as ridges or trenches, or physiological barriers associated with depth. We analyzed biodiversity and biogeography of 21 morphospecies of the deep-sea isopod family Haploniscidae to investigate barrier effects to species dispersal in the KurilKamchatka Trench (KKT) area in the Northwest (NW) Pacific. Our study is based on 2652 specimens from three genera, which were collected during the German-Russian KuramBio I (2012) and II (2016) expeditions as well as the Russian-German SokhoBio (2015) campaign. The sampling area covered two potential geographical barriers (the Kuril Island archipelago and the Kuril-Kamchatka Trench), as well as three depth zones (bathyal, abyssal, hadal). We found significant differences in relative species abundance between abyssal and hadal depths. Haploniscus belyaevi Birstein, 1963 was the dominant species at abyssal stations while $H$. hydroniscoides Birstein, 1963 was prevalent in the hadal. Species composition also differed significantly across geographical barriers. While $H$. hydroniscoides was the most abundant species in the open NW Pacific, not a single specimen of this species was found in the Sea of Okhotsk, which is separated from the Pacific basin by the Kuril Islands. Furthermore, $H$. belyaevi and two morphologically highly similar morphospecies were the only species found in samples from the Sea of Okhotsk, meaning that the other 18 species, which we identified from our samples, did not occur west of the Kuril Islands. In this study, haploniscid species show very diverse patterns in geographic distribution between geographic areas and with depth. Therefore, the KKT might have an isolating effect on both the bathymetric as well as geographic distribution of some haploniscid species from the NW Pacific into the Sea of Okhotsk and from the western to the eastern abyssal margin of the KKT.
\end{abstract}

\section{Introduction}

Within the last 20 years, mechanisms of species formation have been thoroughly investigated for terrestrial and shallow-water ecosystems (Bowen et al., 2013; Butlin et al., 2012; Nosil, 2012; Sobel et al., 2010). Yet, little is known about drivers of speciation in the deep sea, the largest evolutionary realm on Earth (Ramirez-Llodra et al., 2010). Due to a lack of data on the spatial and temporal scales of population differentiation below $200 \mathrm{~m}$ water depth (Zardus et al., 2006), the origin of the encountered species richness in the deep sea is still widely unexplained (Etter and Mullineaux, 2001; Hessler and Sanders, 1967; Sanders, 1968; Snelgrove and Smith, 2002; Stuart et al., 2003).

In the deep sea, the most common scenario for the formation of new species is allopatric speciation. The driving force in this case is an extrinsic barrier that hinders the continuous dispersal of individuals, and hence genetic exchange, within a population. The resulting subpopulations undergo independent genetic differentiation, which finally leads to intrinsic reproductive isolation and consequently separate species. Studying biodiversity forms the basis to infer species ranges, biogeographic patterns and connectivity of populations, which in turn provide information on potential allopatric speciation events (e.g., Wilson and Hessler, 1987).

Early researchers such as Forbes (1859) identified biogeographic provinces as centers for the origin of species in the marine realm, for instance differentiating between Arctic, Boreal and Mediterranean provinces (Forbes, 1859). These provinces were characterized by a significant level of endemism and a unique combination of ecological conditions. Typically, their boundaries corresponded to geographic

\footnotetext{
* Corresponding author at: Goethe University, Biosciences, Institute for Ecology, Evolution und Diversity, Max-von-Laue-Str. 13, 60438 Frankfurt am Main, Germany.

E-mail address: angelika.brandt@senckenberg.de (A. Brandt).
} 
features, such as trenches or ridges, and marked transitions in species occurrence and/or other environmental variables. Watling et al. (2013) proposed a new delineation of biogeographic provinces on a global scale using data on species distribution, water mass characteristics and particulate organic-matter flux. In this approach, much importance was given to depth-related factors resulting in separate provinces for the lower bathyal (800-3500 m depth), abyssal (3500-6000 m depth) and hadal benthos ( $>6000 \mathrm{~m}$ depth). According to this study, the bathymetry of our sampling area in the Northwest (NW) Pacific in close vicinity of the Kuril-Kamchatka Trench (KKT) provides conditions for the formation of three adjacent deep-sea benthic provinces (Watling et al., 2013).

The Sea of Okhotsk, sampled in 2015 during the Russian-German SokhoBio campaign, belongs to the Northern Pacific Boreal province, which is the shallowest of the three provinces in the NW Pacific (mean depth $2381 \mathrm{~m}$ ). The southeastern margin of the Sea of Okhotsk is formed by the Kuril Ridge, which partially rises above sea level and constitutes the Kuril Island archipelago featuring relatively shallow sills. Consequently, benthic organisms have to pass bathyal depths to migrate between the Sea of Okhotsk and the open NW Pacific, for example via the Bussol $(2318 \mathrm{~m})$ and Krusenstern straits $(1920 \mathrm{~m})$. The semi-enclosed location also promotes the specific ecological conditions of the Sea of Okhotsk. Cold intermediate water masses from the Sea of Okhotsk flow southeastwards into the NW Pacific, and deep water masses from the open ocean enter the Sea of Okhotsk via the Bussol and Krusenstern straits, where they sink into the Kuril basin (see Brandt et al. (this issue) for map displaying main currents). This exchange of water masses also promotes an exchange of pelagic and benthic organisms (Tyler, 2002; Ushakov, 1953).

Southeast of the Kuril Ridge, the shallowest of the three provinces borders with the deepest, the hadal KKT with a maximum depth of about 9500 m (Klaeschen et al., 1994). Following Watling et al. (2013), it belongs to the hadal Aleutian-Japan province. The KKT is one of the deepest trenches of the world's ocean, located in a eutrophic area of the Pacific Ocean (Belyaev, 1989; Dreutter et al., this issue; Jamieson, 2015; Jamieson et al., 2010). Moreover, it has the second (after the IzuBonin Trench) largest area of hadal habitat. It is characterized by abundant and diverse hadal bottom fauna (Brandt et al., this issue). Deep flows on the inshore slope of the KKT southeast off Cape Erimo, Hokkaido, show that the lower flows ( $>3000 \mathrm{~m}$ ) are controlled by the local bottom topography and form in part a southward deep western boundary current (Uehara and Miyake, 1999).

The third benthic province in this area, simply named the North Pacific (Watling et al., 2013), comprises of the abyssal plain of the NW Pacific and has an average depth of $4982 \mathrm{~m}$. The boreal Pacific fauna is faunistically influenced by the NW Pacific fauna, especially by the fauna around the Kuril Islands, as well as the Sea of Okhotsk (Kussakin, 1979; Skarlato, 1974; Tyler, 2002). Species of this area could migrate from the Sea of Japan as well as the neighboring Kuril-Kamchatka area via shallow-water connections. The Kuril-Kamchatka area of the NW Pacific has been intensively investigated by Russian scientists between 1949, 1957 and 1966 during the expeditions of the RV Vitjaz (Belyaev, 1989, 1983; Ushakov, 1952).

In summary, the NW Pacific in close vicinity to the Sea of Okhotsk and the KKT is especially interesting to study the biogeography of benthic deep-sea organisms, as it comprised three adjacent biogeographic provinces covering all three depth zones of the deep sea and, furthermore, features a ridge and a trench as potential geographic barriers, which might restrict species dispersal and promote speciation.

Isopoda of the NW Pacific have been described by several researchers, however, most species descriptions, based on the material of the RV Vityaz, were done by Birstein (e.g., 1963, 1970, 1971) and Kussakin over several volumes (e.g., Kussakin, 1965, 1971, 1979, 1982). The Isopoda were one of the most dominant taxa in terms of species richness in the deep-water macrobenthos (Birstein, 1971, 1970, 1963; Kussakin, 2004, 1999, 1971; Kussakin and Vasina, 1990).
Nevertheless, Birstein (1971) noticed that large fractions of the fauna had probably not been sampled due to inappropriate sampling gear and methods used for sieving and washing, therefore the true deep-sea biodiversity might have been only partly studied.

For this study, we focused on the Haploniscidae - an abundant and speciose family of macrobenthic Isopoda in the NW Pacific (Elsner et al., 2015; Golovan et al., 2019). Kussakin (1988) summarized the knowledge of the Haploniscidae from KKT. He referred to the 19 species of the genus Haploniscus Richardson, 1908, one species each of the genera Chauliodoniscus Lincoln, 1985, and Abyssoniscus Birstein, 1971, three species of Hydroniscus Hansen, 1916, and two species of Antennuloniscus Menzies, 1962 which occurred from the shelf down to hadal depths of this area.

Isopods are brooders and therefore are thought to have a reduced gene flow and exhibit species complexes (e.g., Brix et al., 2015; Brökeland, 2010; Brökeland and Raupach, 2008; Schnurr et al., 2018; Wilson, 1982). Thus, using the Haploniscidae, we seek to test the following hypotheses: firstly, that the biogeographic patterns of isopod species in the KKT area reflect the boundaries of biogeographic provinces - the boundaries act as barriers for species dispersal due to significant changes in ecological conditions, thus promoting speciation along theses gradients; and, secondly, that the effects of the ecological gradients related to the boundaries of biogeographic provinces are higher than the effect of isolation by distance within each of the provinces.

\section{Material and methods}

\subsection{Sampling}

The material analyzed in this study was collected during three successive deep-sea expeditions in the NW Pacific: KuramBio I (Kuril Kamchatka Biodiversity Studies I (Brandt and Malyutina, 2012)), SokhoBio (Sea of Okhotsk Biodiversity Studies (Malyutina et al., 2015)), and KuramBio II (Kuril Kamchatka Biodiversity Studies II (Brandt and shipboard scientific party, 2016)).

The KuramBio I (KB I) campaign focused on sampling the open abyssal plains of the NW Pacific basin $(\sim 5000 \mathrm{~m}$ depth) adjacent to the eastern slope of the KKT. It was followed by the SokhoBio (SKB) expedition with bathyal and abyssal stations in the semi-enclosed Sea of Okhotsk, which is separated from the Pacific Ocean by the Kuril Islands and the Kamchatka Peninsula. The majority of samples from this campaign were taken from the deepest area, the Kuril basin, which has a maximum depth of $3374 \mathrm{~m}$. In addition, samples were collected along the Bussol Strait $(\sim 2300 \mathrm{~m}$ depth) to investigate the connectivity between the Sea of Okhotsk and the Pacific Basin. The third expedition, KuramBio II (KB II), was conducted to collect samples from hadal depths of the KKT, as well as from the adjacent abyssal Pacific plains. Hence, the area investigated ranged from the southern Sea of Okhotsk across the Bussol Strait and the KKT to the abyssal plains of the NW Pacific Basin, covering depths from $1694 \mathrm{~m}$ to $9584 \mathrm{~m}$ (Fig. 1). All samples we refer to were collected using an epibenthic sledge (EBS) (Brandt et al., 2013; Brenke, 2005) from a total of 51 stations (representing one haul each) (Table 1) located within 34 sampling areas (Fig. 1). They were fixed in $96 \%$ ethanol and kept at $-20{ }^{\circ} \mathrm{C}$ as described by Riehl et al. (2014) to prevent DNA degradation and to allow subsequent genetic studies. The material was sorted using stereomicroscopes and all specimens of Haploniscidae were identified to species level (morphospecies) based on morphological clustering (Hausdorf, 2011) and compared to original descriptions and type material. The examined haploniscid material is deposited at the Museum of Institute of Marine Biology, Vladivostok, Russia (MIMB) (SKB samples), the Senckenberg Natural History Museum Frankfurt, Germany (KB I (partial) and KB II samples) and the Zoological Museum, Centre for Natural History, University of Hamburg, Germany (partial KB I samples). 


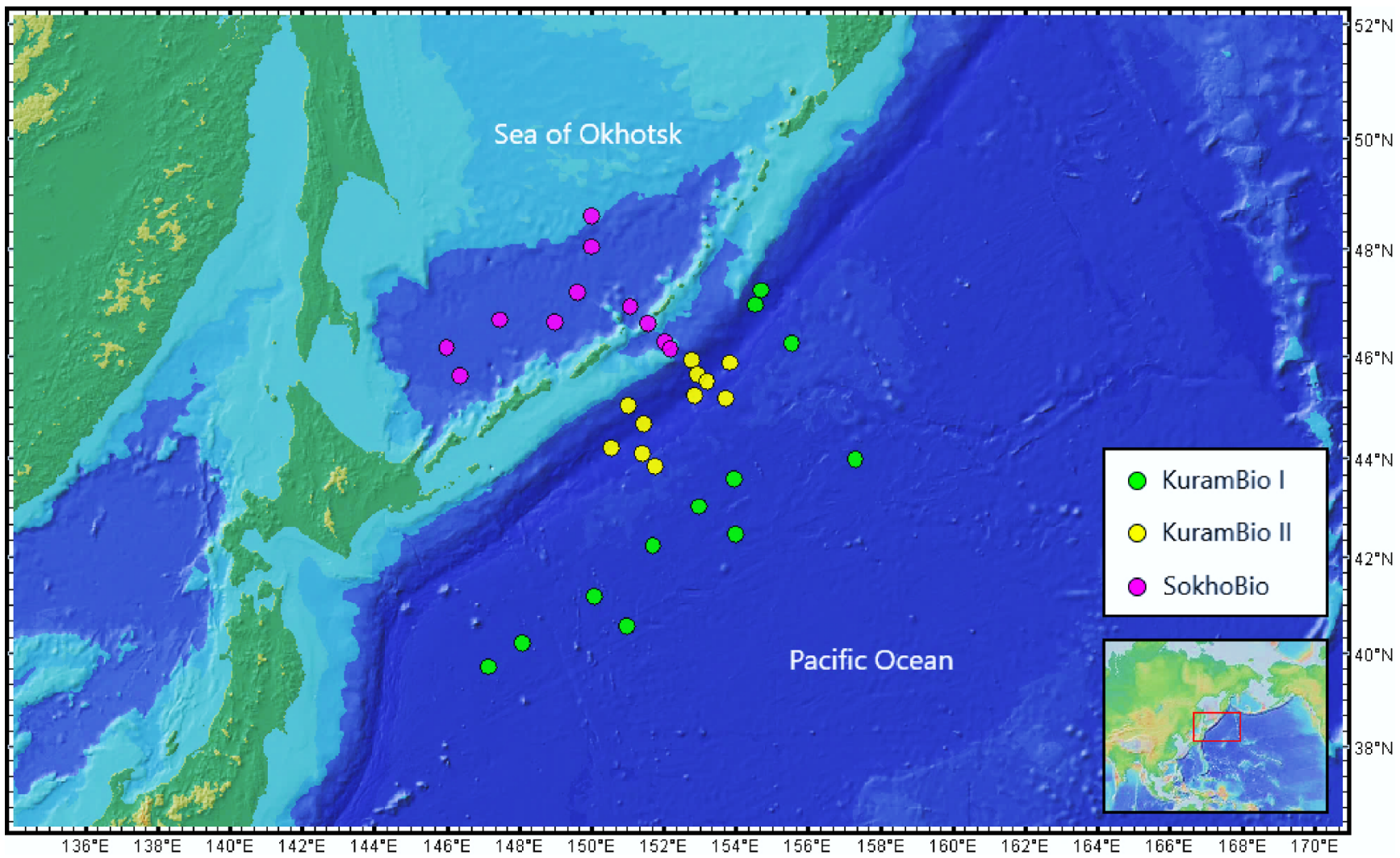

Fig. 1. Sampling areas of the KuramBio I, KuramBio II, and SokhoBio expeditions.

\subsection{Data analyses}

Analyses on the biodiversity and biogeography of species were carried out in PRIMER version 6.1.11 (Clarke and Gorley, 2006) with PERMANOVA + version 1.0.1 (Anderson et al., 2008) implemented as an add-on.

Bray-Curtis similarity matrices were built for the univariate data on species richness (S), total abundance (n), Pielou's evenness $\left(\mathrm{J}^{\prime}\right)$, Shannon-Wiener diversity $\left(\mathrm{H}^{\prime}\right)$, and the multivariate data on relative species abundance (RA). A non-parametric ANOVA with 9999 permutations was conducted for all indices under two different nested designs to investigate differences between water depth and geographical zones (Table 2).

The first design was established to test for differences between abyssal (3000-6500 m) and hadal (> $6500 \mathrm{~m}$ ) depths. The bathyal was excluded from the analysis as no specimens of Haploniscidae were collected from this depth zone. The second design was built to examine the differences between geographical zones. The geo zones were derived from the definition of biogeographic provinces by Watling et al. (2013), following natural boundaries in the bathymetry, which potentially act as barriers to dispersal for the Haploniscidae. The definition for the Sea of Okhotsk and the KKT were adopted from Watling et al. (2013). However, we slightly adjusted their design by shifting the boundary for abyssal to $>3000 \mathrm{~m}$ and for hadal to $>6500 \mathrm{~m}$ to reflect local characteristics in the bathymetry. Furthermore, we split the North Pacific province into two abyssal zones, east and west of the KKT. Thus, we could discriminate the barrier effect of the trench from the pure depth difference between abyssal and hadal. Accordingly, our analysis was based on four geo zones: Sea of Okhotsk (SOO), west-trench abyssal (WTA), central-trench hadal (CTH), and east-trench abyssal (ETA). The sampling areas of the three expeditions were accordingly assigned to these four geographical zones (Fig. 2).

Significant differences between groups were considered when $p<0.05$. Non-parametric pairwise t-tests were conducted for the "geo zone" design when PERMANOVA analyses yielded significant results. Consequently, the homogeneity of multivariate dispersions between groups was tested in a PERMDISP analysis. Finally, a SIMPER analysis was conducted to calculate the average contribution to dissimilarity between depth zones and geographical zones for each taxon (Anderson et al., 2008). To assess the influence of a sampling bias in our analysis, we further prepared rarefaction curves using the non-parametric chao1 estimator for the different depth and geographical zones.

Maps were generated using GeoMapApp (http://www.geomapapp. org/) and graphic illustrations were prepared with Microsoft ${ }^{\circledR}$ Excel and Adobe $^{\circledast}$ Illustrator ${ }^{\circledast}$.

\section{Results}

In total, 2652 individuals of the isopod family Haploniscidae from samples of the KBI, SKB, and KBII expeditions were determined to species level. They were allocated to 21 morphospecies belonging to three genera Haploniscus Richardson, 1908, Hydroniscus Hansen, 1916, and Mastigoniscus Lincoln, 1985. Six of these species were already known to science from the Vitjaz expeditions in the 1950s and 1960s (Birstein, 1971, 1963) (Table 3).

The most specious genus from all expeditions was Haploniscus represented by 13 morphospecies, followed by Mastigoniscus with six species, and Hydroniscus with two species. The most abundant species was $H$. hydroniscoides Birstein, 1963 comprising 1137 (42.87\%) of all examined individuals. It was followed by $H$. belyaevi Birstein, 1963 with 838 (31.6\%), and H. gibbernasutus Birstein, 1971 with 178 (6.7\%) individuals. Twelve morphospecies were only represented by between one to ten individuals in total. A species complex comprising $H$. belyaevi and four highly similar but undescribed morphospecies, named Haploniscus aff. $H$. belyaevi A-D, could be identified. 
Table 1

Station data of examined epibenthic sledge (EBS) samples.

\begin{tabular}{|c|c|c|c|c|c|c|}
\hline Expedition & Area & Station & Date & Latitude start & Longitude start & depth [m] \\
\hline KuramBio I & KBI_A1 & KBI_1-10 & 30.07 .2012 & $43^{\circ} 58.35^{\prime} \mathrm{N}$ & $157^{\circ} 18.23^{\prime} \mathrm{E}$ & 5423 \\
\hline KuramBio I & KBI_A2 & KBI_2-9 & 03.08 .2012 & $46^{\circ} 14.78^{\prime} \mathrm{N}$ & $155^{\circ} 32.63^{\prime} \mathrm{E}$ & 4830 \\
\hline KuramBio I & KBI_A3 & KBI_3-9 & 05.08 .2012 & $47^{\circ} 14.66^{\prime} \mathrm{N}$ & $154^{\circ} 42,88^{\prime} \mathrm{E}$ & 4987 \\
\hline KuramBio I & KBI_A4 & KBI_4-3 & 06.08 .2012 & $46^{\circ} 58.34{ }^{\prime} \mathrm{N}$ & $154^{\circ} 33.03^{\prime} \mathrm{E}$ & 5681 \\
\hline KuramBio I & KBI_A5 & KBI_5-9 & 11.08 .2012 & $43^{\circ} 34.46^{\prime} \mathrm{N}$ & $153^{\circ} 58.13^{\prime} \mathrm{E}$ & 5376 \\
\hline KuramBio I & KBI_A6 & KBI_6-11 & 15.08 .2012 & $42^{\circ} 28.61^{\prime} \mathrm{N}$ & $153^{\circ} 59.68^{\prime} \mathrm{E}$ & 5305 \\
\hline KuramBio I & KBI_A7 & KBI_7-9 & 17.08 .2012 & $43^{\circ} 01.78^{\prime} \mathrm{N}$ & $152^{\circ} 58.61^{\prime} \mathrm{E}$ & 5222 \\
\hline KuramBio I & KBI_A8 & KBI_8-9 & 20.08 .2012 & $42^{\circ} 14.32^{\prime} \mathrm{N}$ & $151^{\circ} 42.68^{\prime} \mathrm{E}$ & 5125 \\
\hline KuramBio I & KBI_A9 & KBI_9-9 & 23.08 .2012 & $40^{\circ} 34.51^{\prime} \mathrm{N}$ & $150^{\circ} 59.92^{\prime} \mathrm{E}$ & 5399 \\
\hline KuramBio I & KBI_A10 & KBI_10-9 & 26.08 .2012 & $41^{\circ} 11.37^{\prime} \mathrm{N}$ & $150^{\circ} 05.63^{\prime} \mathrm{E}$ & 5264 \\
\hline KuramBio I & KBI_A11 & KBI_11-9 & 29.08 .2012 & $40^{\circ} 12.49^{\prime} \mathrm{N}$ & $148^{\circ} 05.40^{\prime} \mathrm{E}$ & 5263 \\
\hline KuramBio I & KBI_A12 & KBI_12-4 & 31.08 .2012 & $39^{\circ} 42.78^{\prime} \mathrm{N}$ & $147^{\circ} 09.55^{\prime} \mathrm{E}$ & 5224 \\
\hline SokhoBio & SKB_A1 & SKB_1-8 & 10.07 .2015 & $46^{\circ} 08.88^{\prime} \mathrm{N}$ & $146^{\circ} 00.26^{\prime} \mathrm{E}$ & 3307 \\
\hline SokhoBio & SKB_A1 & SKB_1-9 & 10.07 .2015 & $46^{\circ} 05.04^{\prime} \mathrm{N}$ & $146^{\circ} 00.47^{\prime} \mathrm{E}$ & 3307 \\
\hline SokhoBio & SKB_A2 & SKB_2-7 & 13.07.2015 & $46^{\circ} 40.96^{\prime} \mathrm{N}$ & $147^{\circ} 28.28^{\prime} \mathrm{E}$ & 3351 \\
\hline SokhoBio & SKB_A2 & SKB_2-8 & 13.07 .2015 & $46^{\circ} 41.09^{\prime} \mathrm{N}$ & $147^{\circ} 27.39^{\prime} \mathrm{E}$ & 3351 \\
\hline SokhoBio & SKB_A3 & SKB_3-9 & 15.07 .2015 & $46^{\circ} 38.00^{\prime} \mathrm{N}$ & $148^{\circ} 59.36^{\prime} \mathrm{E}$ & 3363 \\
\hline SokhoBio & SKB_A3 & SKB_3-10 & 15.07 .2015 & $46^{\circ} 37.90^{\prime} \mathrm{N}$ & $148^{\circ} 59.90^{\prime} \mathrm{E}$ & 3363 \\
\hline SokhoBio & SKB_A4 & SKB_4-9 & 17.07 .2015 & $47^{\circ} 12.13^{\prime} \mathrm{N}$ & $149^{\circ} 37.14^{\prime} \mathrm{E}$ & 3366 \\
\hline SokhoBio & SKB_A4 & SKB_4-10 & 17.07.2015 & $47^{\circ} 12.04^{\prime} \mathrm{N}$ & $149^{\circ} 36.95^{\prime} \mathrm{E}$ & 3366 \\
\hline SokhoBio & SKB_A5 & SKB_5-6 & 18.07 .2015 & $48^{\circ} 37.47^{\prime} \mathrm{N}$ & $150^{\circ} 00.65^{\prime} \mathrm{E}$ & 1694 \\
\hline SokhoBio & SKB_A5 & SKB_5-7 & 18.07 .2015 & $48^{\circ} 37.38^{\prime} \mathrm{N}$ & $150^{\circ} 00.55^{\prime} \mathrm{E}$ & 1694 \\
\hline SokhoBio & SKB_A6 & SKB_6-6 & 20.07 .2015 & $48^{\circ} 03.26^{\prime} \mathrm{N}$ & $150^{\circ} 00.58^{\prime} \mathrm{E}$ & 3347 \\
\hline SokhoBio & SKB_A6 & SKB_6-7 & 20.07 .2015 & $48^{\circ} 03.23^{\prime} \mathrm{N}$ & $150^{\circ} 00.47^{\prime} \mathrm{E}$ & 3350 \\
\hline SokhoBio & SKB_A7 & SKB_7-3 & 22.07 .2015 & $46^{\circ} 56.56^{\prime} \mathrm{N}$ & $151^{\circ} 05.01^{\prime} \mathrm{E}$ & 3299 \\
\hline SokhoBio & SKB_A7 & SKB_7-4 & 22.07 .2015 & $46^{\circ} 57.47^{\prime} \mathrm{N}$ & $151^{\circ} 05.07^{\prime} \mathrm{E}$ & 3300 \\
\hline SokhoBio & SKB_A8 & SKB_8-4 & 24.07 .2015 & $46^{\circ} 36.39^{\prime} \mathrm{N}$ & $151^{\circ} 34.57^{\prime} \mathrm{E}$ & 2333 \\
\hline SokhoBio & SKB_A8 & SKB_8-5 & 24.07 .2015 & $46^{\circ} 36.36^{\prime} \mathrm{N}$ & $151^{\circ} 34.91^{\prime} \mathrm{E}$ & 2327 \\
\hline SokhoBio & SKB_A9 & SKB_9-6 & 26.07 .2015 & $46^{\circ} 16.10^{\prime} \mathrm{N}$ & $152^{\circ} 02.71^{\prime} \mathrm{E}$ & 3386 \\
\hline SokhoBio & SKB_A9 & SKB_9-7 & 26.07 .2015 & $46^{\circ} 16.16^{\prime} \mathrm{N}$ & $152^{\circ} 03.10^{\prime} \mathrm{E}$ & 3371 \\
\hline SokhoBio & SKB_A10 & SKB_10-5 & 28.07 .2015 & $46^{\circ} 07.41^{\prime} \mathrm{N}$ & $152^{\circ} 11.29^{\prime} \mathrm{E}$ & 4681 \\
\hline SokhoBio & SKB_A10 & SKB_10-6 & 28.07 .2015 & $46^{\circ} 07.70^{\prime} \mathrm{N}$ & $152^{\circ} 09.70^{\prime} \mathrm{E}$ & 4469 \\
\hline SokhoBio & SKB_A10 & SKB_10-7 & 29.07.2015 & $46^{\circ} 06.03^{\prime} \mathrm{N}$ & $152^{\circ} 14.44^{\prime} \mathrm{E}$ & 4769 \\
\hline SokhoBio & SKB_A11 & SKB_11-6 & 01.08 .2015 & $45^{\circ} 36.79^{\prime} \mathrm{N}$ & $146^{\circ} 22.59^{\prime} \mathrm{E}$ & 3210 \\
\hline KuramBio II & KBII_A8 & KBII_8 & 19.08 .2016 & $43^{\circ} 49.55^{\prime} \mathrm{N}$ & $151^{\circ} 46.25^{\prime} \mathrm{E}$ & 5136 \\
\hline KuramBio II & KBII_A8 & KBII_10 & 20.08 .2016 & $43^{\circ} 49.43^{\prime} \mathrm{N}$ & $151^{\circ} 46.96^{\prime} \mathrm{E}$ & 5120 \\
\hline KuramBio II & KBII_A1 & KBII_17 & 22.08 .2016 & $45^{\circ} 52.04^{\prime} \mathrm{N}$ & $153^{\circ} 51.39^{\prime} \mathrm{E}$ & 8191 \\
\hline KuramBio II & KBII_A1 & KBII_19 & 23.08 .2016 & $45^{\circ} 52.02 ’ \mathrm{~N}$ & $153^{\circ} 51.15^{\prime} \mathrm{E}$ & 8196 \\
\hline KuramBio II & KBII_A6 & KBII_28 & 25.08 .2016 & $45^{\circ} 54.43^{\prime} \mathrm{N}$ & $152^{\circ} 47.02^{\prime} \mathrm{E}$ & 6051 \\
\hline KuramBio II & KBII_A6 & KBII_30 & 27.08 .2016 & $45^{\circ} 56.38^{\prime} \mathrm{N}$ & $152^{\circ} 56.70^{\prime} \mathrm{E}$ & 6181 \\
\hline KuramBio II & KBII_A5 & KBII_40 & 29.08 .2016 & $45^{\circ} 38.00^{\prime} \mathrm{N}$ & $152^{\circ} 55.95^{\prime} \mathrm{E}$ & 7081 \\
\hline KuramBio II & KBII_A5 & KBII_42 & 30.08 .2016 & $45^{\circ} 39.62^{\prime} \mathrm{N}$ & $152^{\circ} 56.39^{\prime} \mathrm{E}$ & 7123 \\
\hline KuramBio II & KBII_A4 & KBII_52 & 06.09 .2016 & $45^{\circ} 29.77^{\prime} \mathrm{N}$ & $153^{\circ} 12.16^{\prime} \mathrm{E}$ & 8737 \\
\hline KuramBio II & KBII_A4 & KBII_55 & 06.09 .2016 & $45^{\circ} 29.24^{\prime} \mathrm{N}$ & $153^{\circ} 13.46^{\prime} \mathrm{E}$ & 8745 \\
\hline KuramBio II & KBII_A3 & KBII_65 & 09.09 .2016 & $45^{\circ} 09.85^{\prime} \mathrm{N}$ & $153^{\circ} 43.34^{\prime} \mathrm{E}$ & 5755 \\
\hline KuramBio II & KBII_A7 & KBII_77 & 13.09 .2016 & $45^{\circ} 13.71^{\prime} \mathrm{N}$ & $152^{\circ} 51.21^{\prime} \mathrm{E}$ & 9584 \\
\hline KuramBio II & KBII_A10 & KBII_85 & 15.09 .2016 & $45^{\circ} 02.26^{\prime} \mathrm{N}$ & $151^{\circ} 02.14^{\prime} \mathrm{E}$ & 5265 \\
\hline KuramBio II & KBII_A10 & KBII_87 & 16.09 .2016 & $45^{\circ} 00.76^{\prime} \mathrm{N}$ & $151^{\circ} 05.53^{\prime} \mathrm{E}$ & 5492 \\
\hline KuramBio II & KBII_A9 & KBII_89 & 16.09 .2016 & $44^{\circ} 40.12^{\prime} \mathrm{N}$ & $151^{\circ} 27.35^{\prime} \mathrm{E}$ & 8221 \\
\hline KuramBio II & KBII_A2 & KBII_97 & 18.09 .2016 & $44^{\circ} 05.68^{\prime} \mathrm{N}$ & $151^{\circ} 24.88^{\prime} \mathrm{E}$ & 6575 \\
\hline KuramBio II & KBII_A11 & KBII_102 & 20.09 .2016 & $44^{\circ} 11.99^{\prime} \mathrm{N}$ & $150^{\circ} 34.07^{\prime} \mathrm{E}$ & 9545 \\
\hline
\end{tabular}

Table 2

Factor designs used for uni- and multivariate non-parametric ANOVA.

\begin{tabular}{|c|c|c|c|c|c|}
\hline \multicolumn{3}{|c|}{ Design "depth zone" } & \multicolumn{3}{|c|}{ Design "geo zone" } \\
\hline Factor & Nested in & Effect & Factor & Nested in & Effect \\
\hline station & $\begin{array}{l}\text { area, depth } \\
\text { zone }\end{array}$ & random & station & $\begin{array}{l}\text { area, depth zone, } \\
\text { geo zone }\end{array}$ & random \\
\hline area & depth zone & random & area & $\begin{array}{l}\text { depth zone, geo } \\
\text { zone }\end{array}$ & random \\
\hline depth zone & & fixed & $\begin{array}{l}\text { depth zone } \\
\text { geo zone }\end{array}$ & geo zone & $\begin{array}{l}\text { random } \\
\text { fixed }\end{array}$ \\
\hline
\end{tabular}

\subsection{Differences between depth zones}

The univariate analyses revealed a significantly higher Pielou's evenness $\left(\mathrm{J}^{\prime}\right)(p=0.0473)$ and Shannon-Wiener diversity $\left(\mathrm{H}^{\prime}\right)$ $(p=0.0431)$ in the abyssal stations compared to those in the hadal (Fig. 3). In both cases, the PERMDISP analysis yielded no significant differences in homogeneity of dispersions, which supports inferences on the depth effect. However, no significant depth differences were found in species richness (S) or total abundance (n).

The multivariate analysis of relative species abundance (RA) revealed significant differences between depths $(p=0.0094)$, too, which was again supported by a non-significant PERMDISP result. The SIMPER analysis pointed out three species, which accounted for more than $10 \%$ of the differences each (Fig. 4). H. hydroniscoides contributed most to the differences between depths with $31.64 \%$. It showed higher relative abundance at hadal stations ( $\mathrm{RA}=77.82 \%$ ) compared to abyssal stations $(\mathrm{RA}=26.89 \%$ ), with a depth range of $4469-8745 \mathrm{~m}$ (Vitjaz records: $4790-8120 \mathrm{~m}$ ). It was followed by $H$. belyeavi with $22.76 \%$ contribution to differences between depth, which was in contrast to $H$. hydroniscoides which was more abundant at the abyssal stations $(\mathrm{RA}=42.20 \%)$ than in the hadal $(\mathrm{RA}=8.63 \%) . \mathrm{H}$. belyeavi also occurred at shallower depths than $H$. hydroniscoides, starting at $3210 \mathrm{~m}$, but it was not found deeper than $7123 \mathrm{~m}$ (Vitjaz records: 2415-6225 m). M. latus Birstein, 1971 showed a contribution of 


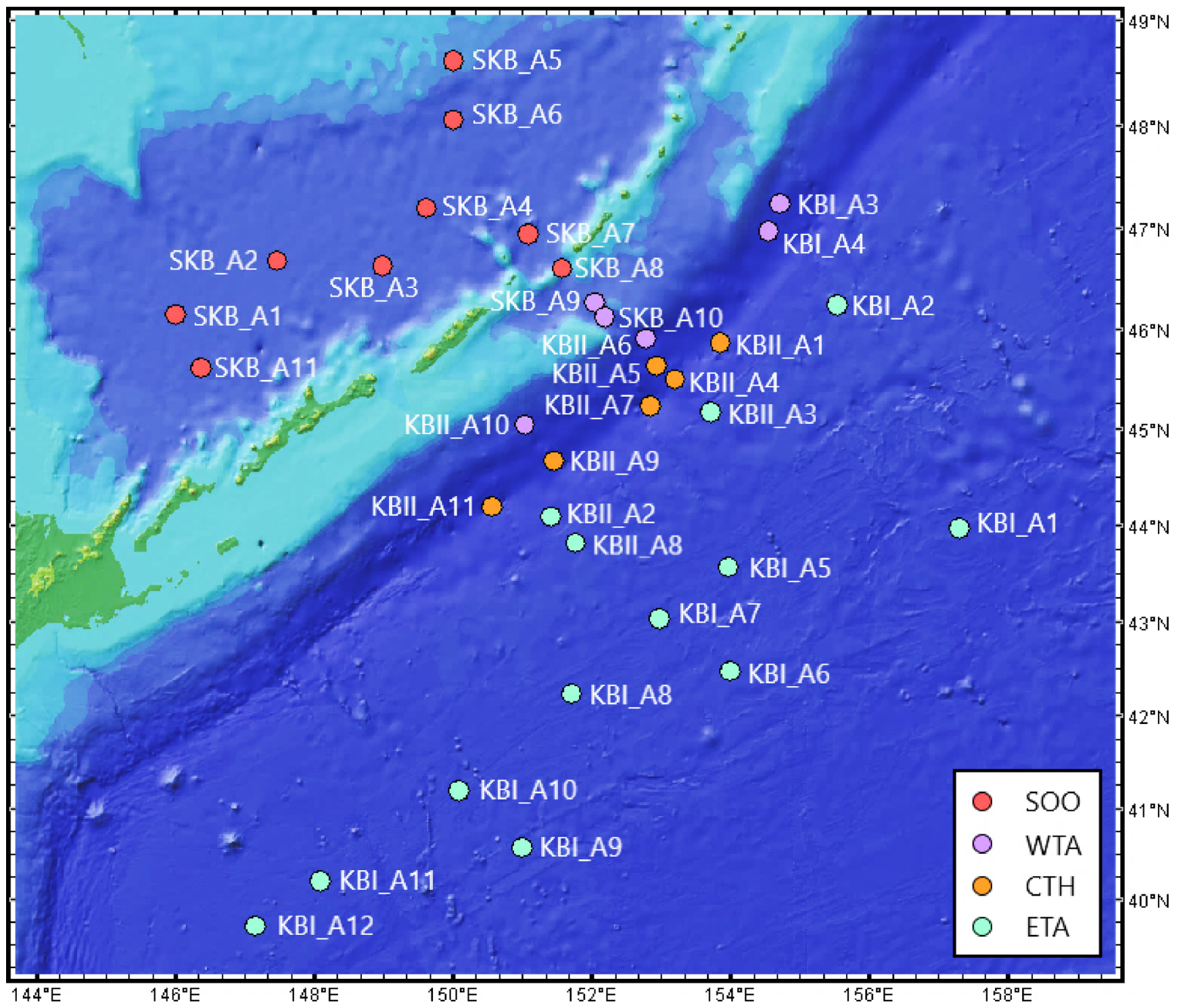

Fig. 2. Sampling areas divided into four geographical zones defined by bathymetric features (KBI: KuramBio I, KBII: KuramBio II; SKB: SokhoBio, SOO: Sea of Okhotsk, WTA: west trench abyssal, CTH: central trench hadal, ETA: east trench abyssal).

$11.37 \%$ to the depth differences in relative abundance. Similar to $H$. hydroniscoides, M. latus was more abundant at the hadal stations $(\mathrm{RA}=5.16 \%)$ and occurred only rarely in the abyss $(\mathrm{RA}=0.66 \%)$. This species was located at depths from $5136 \mathrm{~m}$ up to the deepest station at $9584 \mathrm{~m}$ (Vitjaz records: $5005-8400 \mathrm{~m}$ ). As it was the only known species found at depths below $9000 \mathrm{~m}$, it is now the deepest record for all described Haploniscidae from the Northwest Pacific. The only other morphospecies we detected at this depth was the undescribed $H$. sp. \#23, which is one of the new species only found in KBII samples.

No specimens of Haploniscidae from our samples were found at bathyal stations. Therefore, these stations were excluded from the analysis. However, H. belyaevi was located at bathyal depths during the Vitjaz cruises at stations $2220(2940 \mathrm{~m})$ and $5600(2415 \mathrm{~m})$ (Birstein, 1971, 1963). It remains the only haploniscid species reported from the bathyal and hence the only species, which occurs across all three depth zones in the deep sea of this region. The majority of morphospecies from our samples occurred only at abyssal depths ( 9 of 21 species) or at abyssal and hadal depths ( 8 of 21 species). Only three species were strictly hadal (Fig. 5). The average distance in depth, across which species were distributed, was $2187 \mathrm{~m}$. Haploniscus aff. H. belyaevi A showed the widest distribution in depth with a distance of $5446 \mathrm{~m}$ (between $3299 \mathrm{~m}$ and $8745 \mathrm{~m}$ depth). The narrowest depth distribution was found in $H$. sp. \#25 with 135 m (between $5264 \mathrm{~m}$ and $5399 \mathrm{~m}$ depth).

According to the Chao1 estimation for species richness (Fig. 6), we consider both zones as equally well sampled to represent the actual number of species, as they both reached the asymptote.

\subsection{Differences between geographical zones}

The univariate analyses for differences between geographical zones yielded no significant results for Pielou's evenness $\left(\mathrm{J}^{\prime}\right)$, species richness (S) or total abundance (n). Only Shannon-Wiener diversity $\left(\mathrm{H}^{\prime}\right)$ differed significantly between the east trench abyssal (ETA) and the central trench hadal (CTH) ( $p=0.0062)$, as well as between the ETA and the Sea of Okhotsk (SOO) $(p=0.0319)$. In both cases, Shannon-Wiener diversity was higher in the ETA compared to the other geographical zones (Fig. 7). However, the PERMDISP analysis also showed significant differences in the homogeneity of dispersions between groups. Hence, the statistical differences found between geographical zones cannot be unambiguously traced to a location effect, i.e. part of the differences 
Table 3

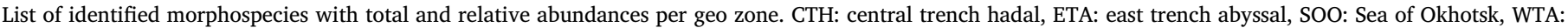
west trench abyssal.

\begin{tabular}{|c|c|c|c|c|c|c|c|c|}
\hline Species name & $\mathrm{SOO}$ & & WTA & & $\mathrm{CTH}$ & & ETA & \\
\hline Haploniscus belyaevi Birstein, 1963 & 331 & $65,94 \%$ & 288 & $44,65 \%$ & 72 & $8,63 \%$ & 147 & $21,91 \%$ \\
\hline Haploniscus aff. $H$. belyaevi A & 79 & $15,74 \%$ & 12 & $1,86 \%$ & 23 & $2,76 \%$ & 13 & $1,94 \%$ \\
\hline Haploniscus aff. H. belyaevi B & 0 & $0,00 \%$ & 0 & $0,00 \%$ & 0 & $0,00 \%$ & 8 & $1,19 \%$ \\
\hline Haploniscus aff. H. belyaevi C & 0 & $0,00 \%$ & 3 & $0,47 \%$ & 11 & $1,32 \%$ & 3 & $0,45 \%$ \\
\hline Haploniscus aff. H. belyaevi D & 91 & $18,13 \%$ & 6 & $0,93 \%$ & 0 & $0,00 \%$ & 0 & $0,00 \%$ \\
\hline Haploniscus aff. $H$. belyaevi $\mathrm{E}$ & 1 & $0,20 \%$ & 0 & $0,00 \%$ & 0 & $0,00 \%$ & 0 & $0,00 \%$ \\
\hline Haploniscus $\mathrm{cf}$. $\mathrm{H}$. intermedius & 0 & $0,00 \%$ & 11 & $1,71 \%$ & 0 & $0,00 \%$ & 0 & $0,00 \%$ \\
\hline Haploniscus gibbernasutus Birstein, 1971 & 0 & $0,00 \%$ & 102 & $15,81 \%$ & 1 & $0,12 \%$ & 75 & $11,18 \%$ \\
\hline Haploniscus hydroniscoides Birstein, 1963 & 0 & $0,00 \%$ & 209 & $32,40 \%$ & 649 & $77,82 \%$ & 279 & $41,58 \%$ \\
\hline Haploniscus sp. \#18 & 0 & $0,00 \%$ & 4 & $0,62 \%$ & 0 & $0,00 \%$ & 4 & $0,60 \%$ \\
\hline Haploniscus sp. \#23 & 0 & $0,00 \%$ & 0 & $0,00 \%$ & 9 & $1,08 \%$ & 0 & $0,00 \%$ \\
\hline Haploniscus sp. \#24 & 0 & $0,00 \%$ & 0 & $0,00 \%$ & 1 & $0,12 \%$ & 0 & $0,00 \%$ \\
\hline Haploniscus sp. \#25 & 0 & $0,00 \%$ & 0 & $0,00 \%$ & 0 & $0,00 \%$ & 9 & $1,34 \%$ \\
\hline Hydroniscus minutus Birstein, 1971 & 0 & $0,00 \%$ & 6 & $0,93 \%$ & 0 & $0,00 \%$ & 4 & $0,60 \%$ \\
\hline Hydroniscus vitjazi Birstein, 1963 & 0 & $0,00 \%$ & 0 & $0,00 \%$ & 1 & $0,12 \%$ & 0 & $0,00 \%$ \\
\hline Mastigoniscus latus Birstein, 1971 & 0 & $0,00 \%$ & 1 & $0,16 \%$ & 43 & $5,16 \%$ & 11 & $1,64 \%$ \\
\hline Mastigoniscus sp. \#12 & 0 & $0,00 \%$ & 0 & $0,00 \%$ & 0 & $0,00 \%$ & 9 & $1,34 \%$ \\
\hline Mastigoniscus sp. \#16 & 0 & $0,00 \%$ & 0 & $0,00 \%$ & 7 & $0,84 \%$ & 0 & $0,00 \%$ \\
\hline Mastigoniscus sp. \#20 & 0 & $0,00 \%$ & 0 & $0,00 \%$ & 0 & $0,00 \%$ & 3 & $0,45 \%$ \\
\hline Mastigoniscus sp. \#26 & 0 & $0,00 \%$ & 3 & $0,47 \%$ & 0 & $0,00 \%$ & 0 & $0,00 \%$ \\
\hline Mastigoniscus sp. \#6 & 0 & $0,00 \%$ & 0 & $0,00 \%$ & 17 & $2,04 \%$ & 106 & $15,80 \%$ \\
\hline total & 502 & $100 \%$ & 645 & $100 \%$ & 834 & $100 \%$ & 671 & $100 \%$ \\
\hline
\end{tabular}

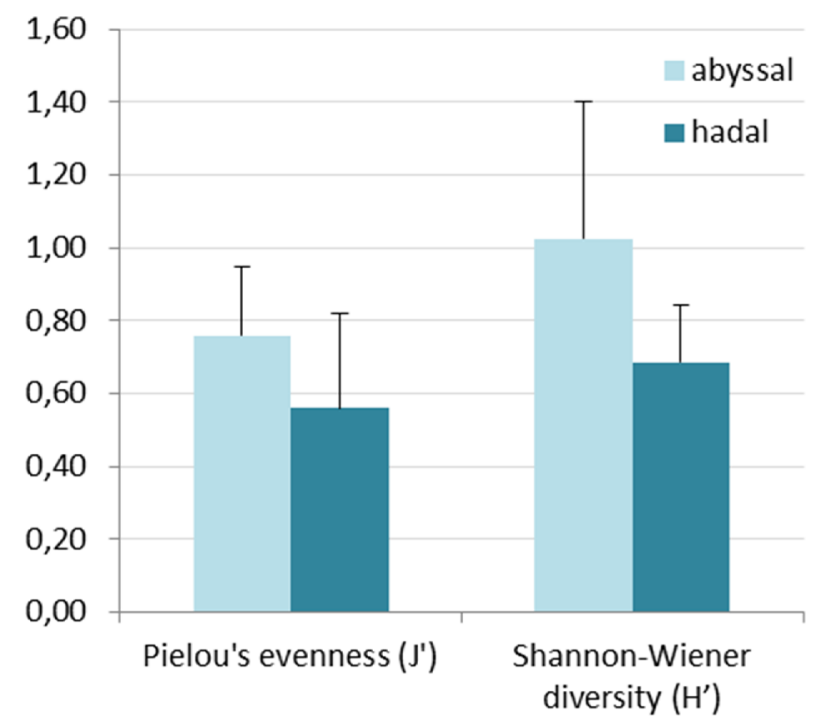

Fig. 3. Average values for Pielou's evenness $\left(\mathrm{J}^{\prime}\right)$ and Shannon-Wiener diversity $\left(\mathrm{H}^{\prime}\right)$ with standard deviations for abyssal and hadal stations.

found might be associated with dispersion of the data.

The same applied to the multivariate analysis of relative species abundance, which showed significant differences between all pairs of geographical zones, but at the same time, significant differences in dispersions between groups. Again, we cannot unambiguously identify a location effect. Nevertheless, the data reflects distinct differences in species composition between geographical zones.

Altogether, the SIMPER results differentiated seven species which accounted for most of the differences between geographical zones, with more than $10 \%$ contribution each (Table 3): $H$. hydroniscoides, $H$. belyaevi, $H$. aff. $H$. belyaevi A, $H$. aff. $H$. belyaevi D, $H$. gibbernasutus, $M$. latus, and $M$. sp. \#6. The combination of species and the amount of contribution differed between pairs of geographical zones. The detailed results of the pairwise comparisons are presented in geographical order from west to east and are visualized in Fig. 8.

Differences between the $\mathrm{SOO}$ and the other zones:

The four most important species contributing to $84.24 \%$ of the cumulative differences in relative species abundance between the SOO and the west trench abyssal (WTA) were $H$. belyaevi, $H$. aff. $H$. belyaevi A, $H$. hydroniscoides, and $H$. aff. $H$. belyaevi D. While $H$. belyaevi together with the morphologically closely related species $H$. aff. $H$. belyaevi A and $H$. aff. $H$. belyaevi D accounted for a total of $99.80 \%$ of the relative species abundance in the SOO, their relative abundance decreased to $47.44 \%$ in the neighboring the WTA. Most of the difference resulted from a distinct decrease in the abundance of $H$. aff. $H$. belyaevi A (RA $=15.74 \%$ vs. $1.86 \%$ ) and $H$. aff. $H$. belyaevi $\mathrm{D}(\mathrm{RA}=18.13 \%$ vs. $0.93 \%$ ) in the the WTA zone compared to SOO, whereas H. belyaevi remained the most abundant species for the WTA (RA $=44.65 \%$ ) as well as for the SOO $(\mathrm{RA}=65.94 \%)$. In contrast, not a single specimen of $H$. hydroniscoides was recorded from the SOO, but it was the second most abundant species in the WTA (RA $=32.40 \%)$.

The same combination of species contributed to $82.14 \%$ of the differences between the SOO and the CTH. The highest contribution resulted from $H$. hydroniscoides (32.06\%), which was absent in the SOO, but showed the highest relative abundance $(\mathrm{RA}=77.82 \%$ ) of all species in the CTH. In contrast, $H$. belyaevi together with $H$. aff. $H$. belyaevi A, which were highly abundant in the SOO, only accounted for $11.39 \%$ of the relative abundance in the $\mathrm{CTH}$, and $H$. aff. $H$. belyaevi D was not detected in this zone.

Differences between the SOO and the ETA reflected similar patterns in species composition. Again, the four species mentioned above accounted for most of the differences between these zones (74.23\%). The $H$. belyaevi complex was more abundant in the SOO compared to the ETA (RA $=99.80 \%$ vs. $22.46 \%$ ). This was mainly due to a decrease in the relative abundance of $H$. aff. $H$. belyaevi A to $0.45 \%$ in the ETA, and because $H$. aff. $H$. belyaevi D was, again, not recorded in this zone. $H$. hydroniscoides, on the contrary, showed a relative abundance of $41.77 \%$ in the ETA and was hence the most abundant species for this zone, although it was absent in the SOO. In addition to the mentioned four species, M. sp. \#6 contributed another $12.03 \%$ to the differences between the SOO and the ETA. It showed a relative abundance of $15.87 \%$ in the ETA, but did not occur in the SOO.

Differences between the WTA and the other zones:

The differences between the WTA and the SOO were already summarized above.

Regarding differences between the WTA and the CTH, H. hydroniscoides, $\mathrm{H}$. belyaevi, and $M$. latus contributed with more than $10 \%$ each. Most of the differences $(31.34 \%)$ could be traced to higher relative abundance of $H$. hydroniscoides in the CTH (RA $=77.82 \%)$ 


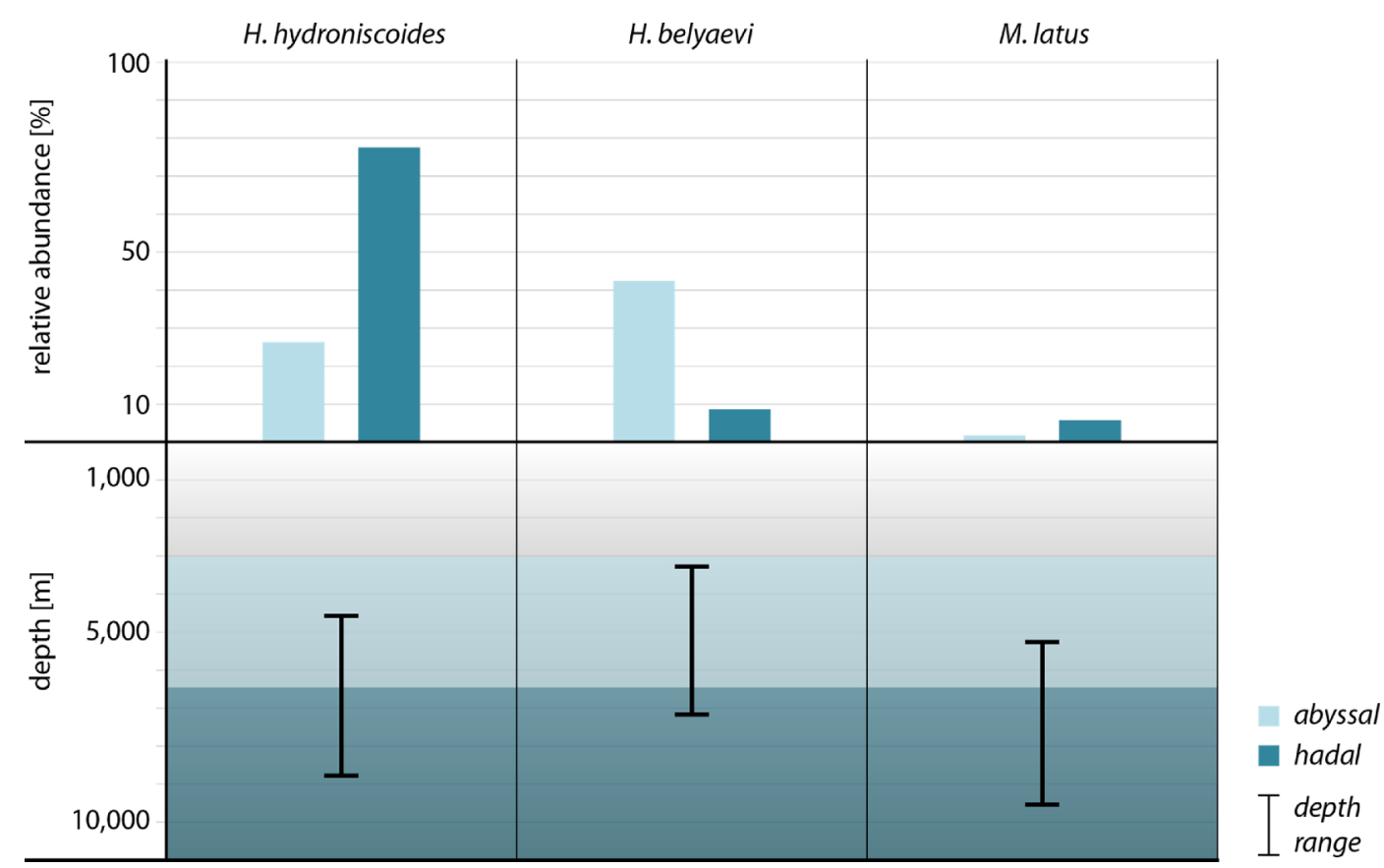

Fig. 4. Relative abundance per depth zone and depth ranges of the three most contributing species regarding depth differences in species composition.

compared to the WTA $(\mathrm{RA}=32.40 \%)$. $\mathrm{H}$. belyaevi contributed $26.30 \%$ to the differences with a relative abundance of $44.65 \%$ in the WTA and only $8.63 \%$ in the CTH. M. latus accounted for $11.58 \%$ of the differences and was, like $H$. hydroniscoides, more frequently found in the $\mathrm{CTH}$ $(\mathrm{RA}=5.16 \%)$ than in the WTA $(\mathrm{RA}=0.16 \%)$.

We also found significant differences between the WTA and the ETA, mainly caused by $H$. belyaevi $(27.20 \%), H$. hydroniscoides (24.19\%), M. sp. \#6 (14.30\%), and H. gibbernasutus (10.01\%). Except for $H$. belyaevi, all species were more abundant in the ETA compared to the WTA. The highest difference between zones was found for $M$. sp. \#6, which showed a relative abundance of $15.87 \%$ in the ETA, while no specimens were recorded for the WTA.

Differences between the CTH and the other zones:

Differences between the CTH, the SOO and the WTA were summarized in the sections above.

The four most important species contributing to differences between the CTH and the ETA were $H$. hydroniscoides $(31.40 \%), H$. belyaevi (14.39\%), M. sp. \#6 (13.44\%), and M. latus (13.35\%). While H. belyaevi and $M$. sp. \#6 showed higher relative abundances in ETA, $H$. hydroniscoides and M. latus were more abundant in the CTH.

Differences between the ETA and the other zones:

See sections above.

The rarefaction curves for the CTH and the ETA reached a plateau, while the rarefaction curves for the SOO and the WTA did not end in an asymptote (Fig. 9). Thus, the actual number of species in the two latter zones might not be fully covered by our samples.

\section{Discussion}

Biodiversity and species composition are influenced by a number of factors, of which habitat size and environmental heterogeneity are amongst the most important (e.g., Chaudhary et al., 2017; Yasuhara et al., 2012). Species richness in the deep sea depends on chemical energy and the carbon flux from the surface in controlling species diversity (McClain et al., 2012; Woolley et al., 2016). Besides these factors, water depth and geography in general might also shape species distribution.

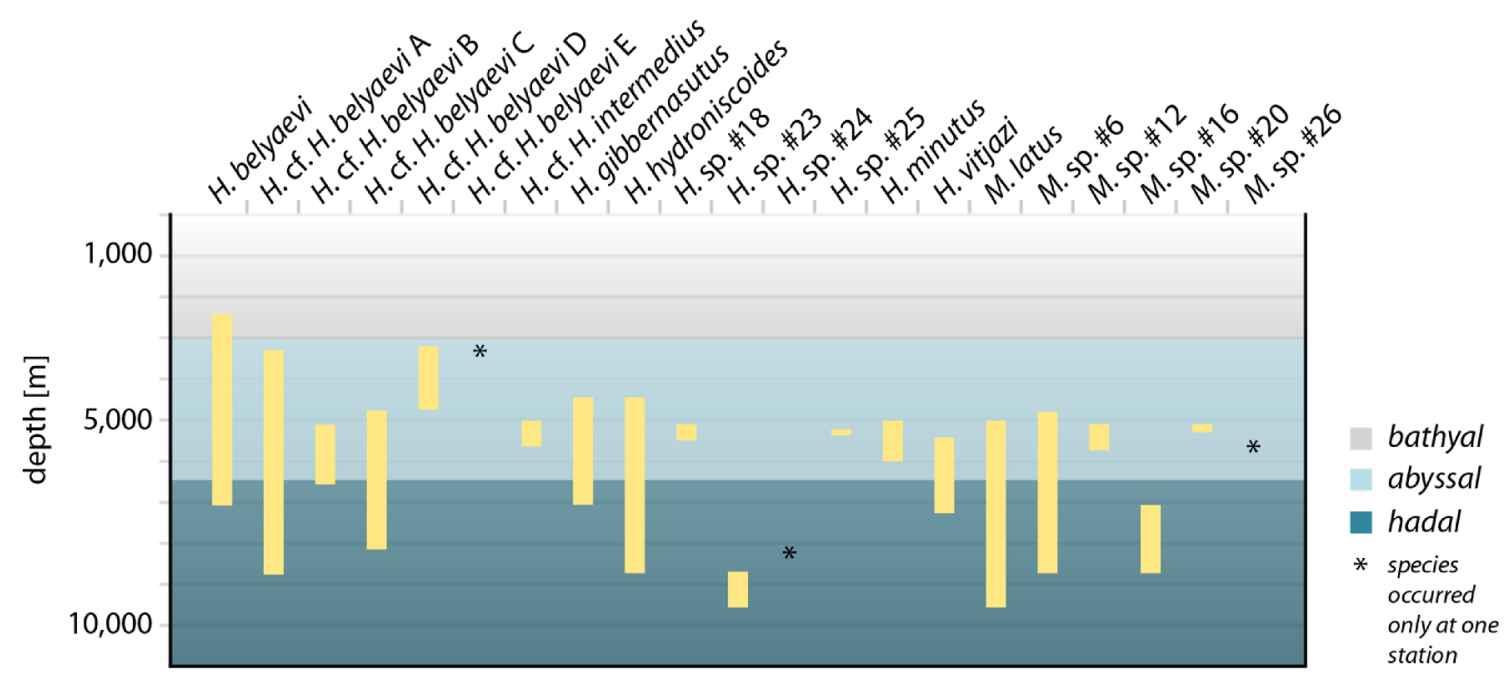

Fig. 5. Depth ranges of all 21 morpho-species found in KuramBio I, SokhoBio, and KuramBio II samples (including depth records from Vitjaz expeditions). 

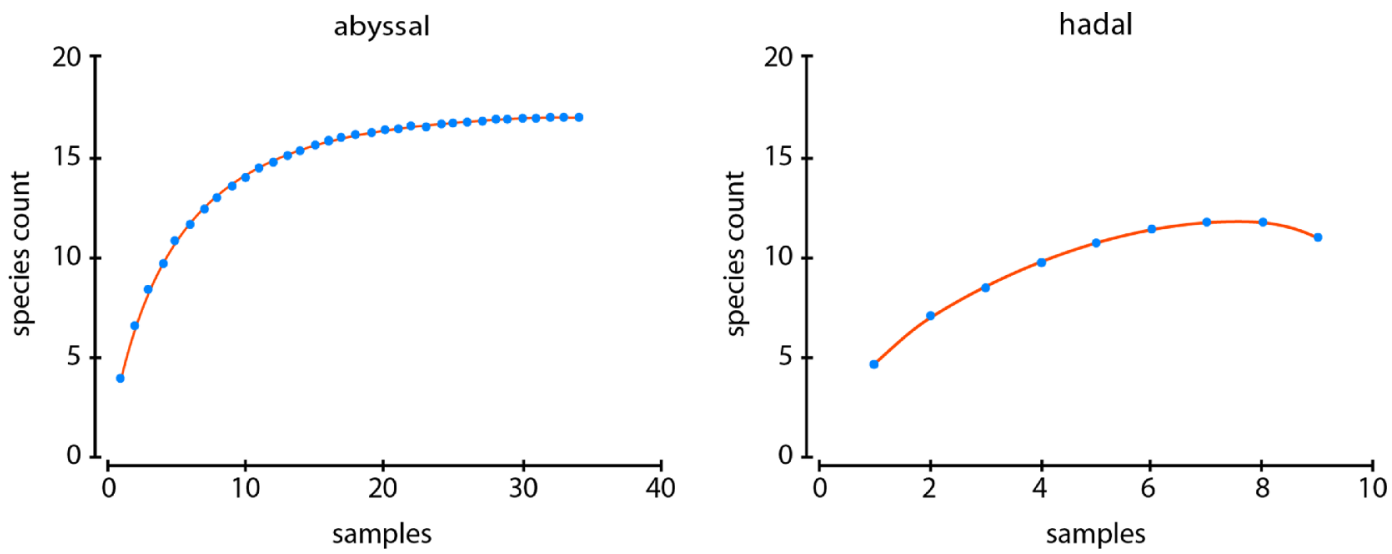

Fig. 6. Rarefaction curves for the abyssal and hadal depth zone.

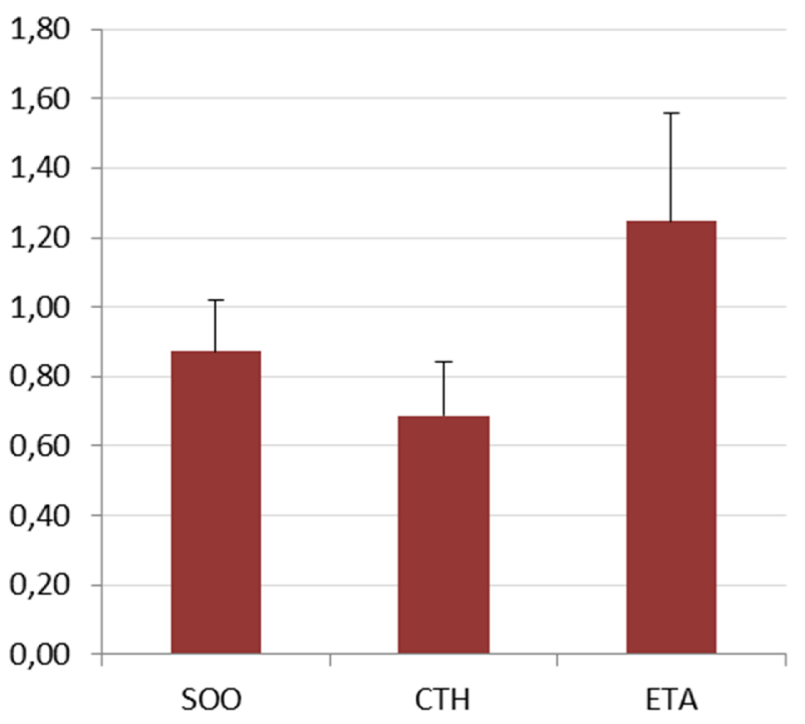

Fig. 7. Average Shannon-Wiener diversity $\left(\mathrm{H}^{\prime}\right)$ with standard deviations for Sea of Okhotsk (SOO), central-trench hadal (CTH), and east-trench abyssal (ETA).

\subsection{Depth differences}

In the deep sea, an increase in evenness with increasing water depth is commonly observed, followed by a decrease in the lower abyssal or hadal regions, while diversity (here Shannon-Wiener index) and richness are generally highest around bathyal depths (Ramirez-Llodra et al., 2010). In our samples, we could also demonstrate an increase in evenness with increasing depth, while diversity and richness decrease in the hadal zone. Even though the results for evenness and diversity in this study follow usual trends encountered for the deep sea, current bathymetry-related trends are dependent on a complex interaction of factors and remain not entirely understood (Brown and Thatje, 2013; Rex et al., 2005).

It might be worth mentioning that no species of the Haploniscidae was found at bathyal stations during the three expeditions we refer to in our analysis. The only known bathyal record for Haploniscidae in this area is for $H$. belyaevi from samples of the Vityaz expeditions (Birstein, 1963). Of all Haploniscidae sampled, twelve species were detected in only one depth zone, nine of them in the abyssal, three of them in the hadal zone. The remaining nine species occurred across the two depth zones. Of course, these findings could be due to sampling bias, as it is known that the less well sampled an area is, the less individuals are usually sampled, and thus the smaller the number and the range (compare, e.g., Brandt et al., 2014). However, only three species of Haplonsicidae (H. sp. \#23 and \#24, and M. sp. \#16) seem to be endemic for the hadal KKT, while nine species ( $H$. belyaevi, $H$. aff. $H$. belyaevi A-C, $H$. gibbernasutus, $H$. hydroniscoides, $H$. vitjazi, M. latus, and M. sp. \#6) show a eurybathic distribution. Hence, our findings contradict the hypothesis of high hadal endemism. The narrow depth distribution of $H$. sp. \#25 with $135 \mathrm{~m}$ depth range (between $5264 \mathrm{~m}$ and $5399 \mathrm{~m}$ depth) can most likely be attributed to sampling bias.

Many marine species are described to occur over wide bathymetrical ranges. However, the concept of eurybathy is challenged, as for some species being widely distributed in the water column, such as the amphipod Eurythenes gryllus (Lichtenstein, 1822), it has been shown that they are in fact species complexes being dependent on depth or water masses (France and Kocher, 1996; Havermans et al., 2013). In this study, $H$. aff. $H$. belyaevi A showed the widest bathymetric distribution over a gradient of $5446 \mathrm{~m}$ from $3299 \mathrm{~m}$ to $8745 \mathrm{~m}$ depth. Interestingly, it is possible that this species is a manca stage of $H$. belyaevi, which has been found much deeper than the adults, possibly supporting the theory of Rex et al. (2005). In their study, they propose a source-sink hypothesis for abyssal Gastropoda, an approach assuming that the abyssal molluscan fauna largely represents deeper range extensions for a subset of bathyal species. A potential advantage of such a distribution could also be the avoidance of competition and predation of the young stages, which might have their cradle in the hadal. However, at this stage we cannot confirm conspecifity of the two abovementioned species or stage-specific depth preferences as we lack the genetic data to test our theory.

The isopod family Ischnomesidae, obtained from the same study area, occurs with 36 species from four genera in the KKT and the Sea of Okhotsk (Bober et al., this issue). Some species of Ischnomesidae occur horizontally over a wide geographic distance along the trench, but most species were only found on one margin and are restricted to a relatively narrow depth range. This indicates that the KKT might isolate these species and prevent gene flow between the western and eastern abyssal slopes of the trench, between the Sea of Okhotsk and the open NW Pacific, as well as along a vertical gradient. Thus, the KKT serves as an isolation barrier for the poorly dispersing benthic species of Ischnomesidae (Bober et al., this issue).

Amongst the isopod family Macrostylidae Macrostylis grandis Birstein, 1970 has a distribution across the KKT at abyssal and upper hadal depths. This indicates that the trench may not represent a barrier for this species (Riehl and Kühn, this issue). However, in the cited study genetic data was only available from two nearby station of the same side of the KKT leaving population-genetic insights across the trench wanted for this species (Riehl and Kühn, this issue). A different picture was shown for Macrostylis sabinae Bober, Riehl, Brandt, 2018 which also has a wide distribution in the NW Pacific, occurring on both sides of the KKT. In this case population-genetic analyses indicated restricted gene flow across the KKT, potentially leading to differentiation between populations (Bober et al., 2018c) which may be the beginning of a speciation event. 


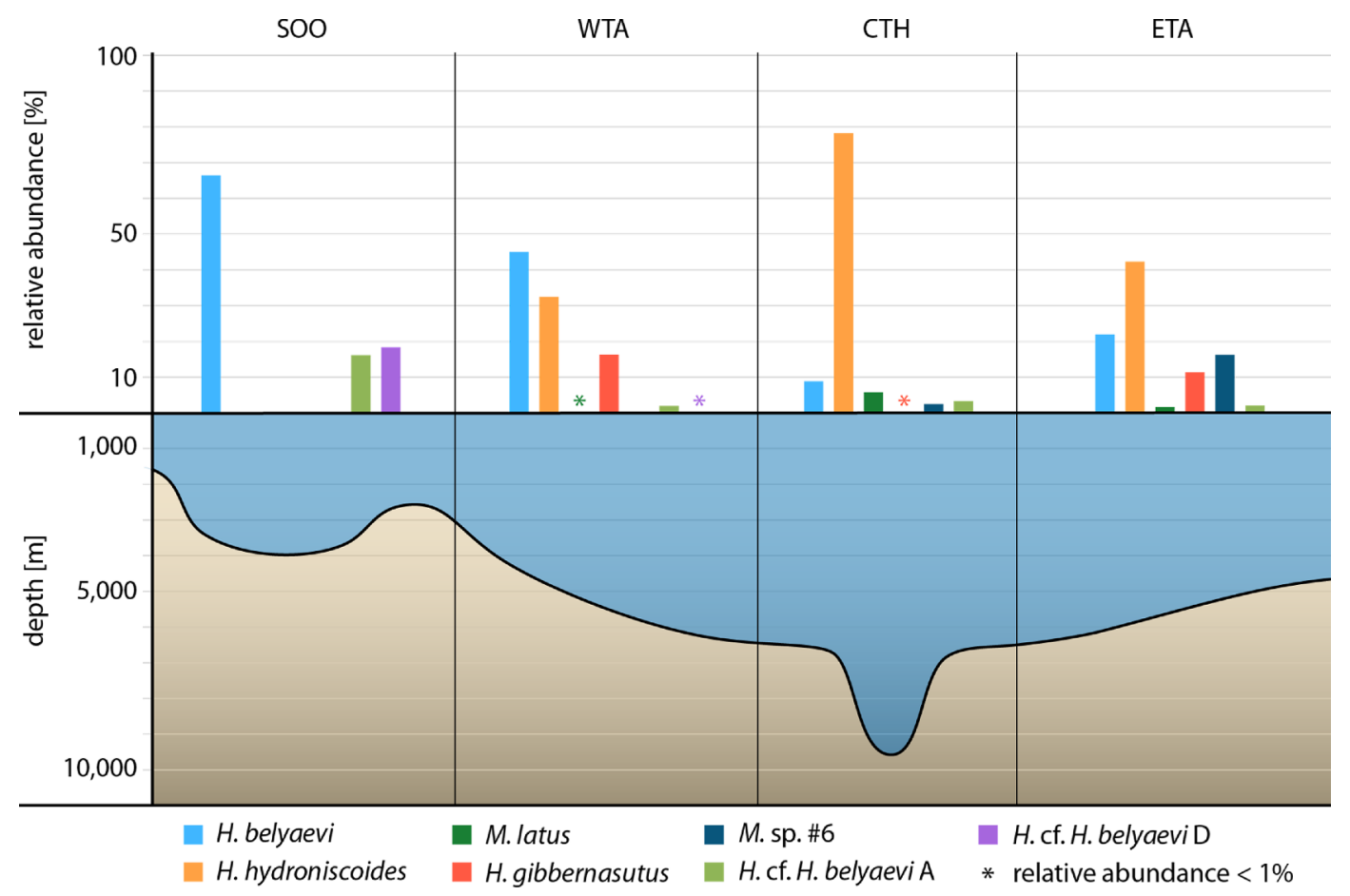

Fig. 8. Relative abundance per geographical zone of the seven most contributing species regarding geographical differences in species composition. CTH: central trench hadal, ETA: east trench abyssal, SOO: Sea of Okhotsk, WTA: west trench abyssal.
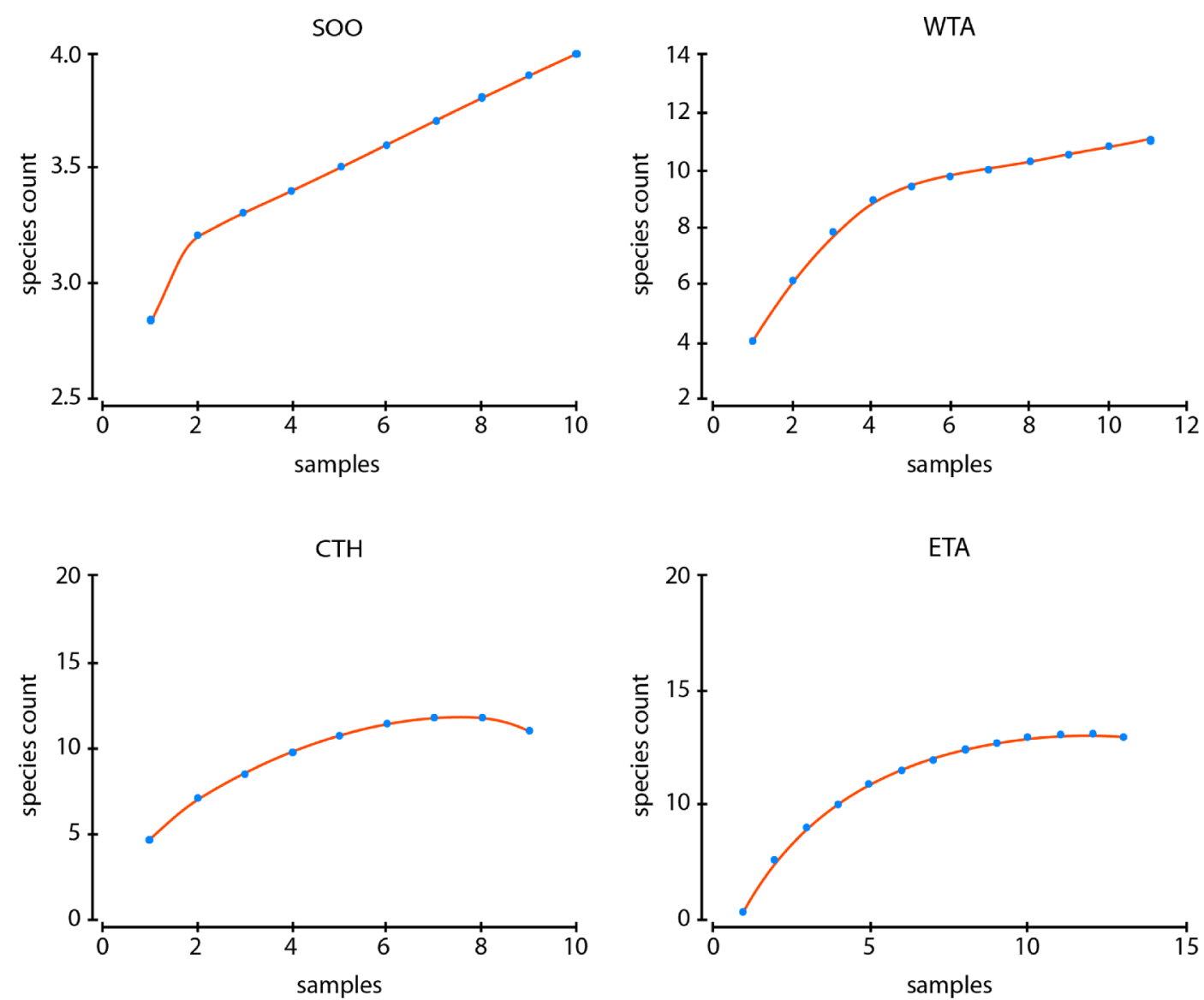

Fig. 9. Rarefaction curves for the four tested geographical zones Sea of Okhotsk (SOO), west trench abyssal (WTA), central trench hadal (CTH), and east trench abyssal (ETA). 
The composition of the Macrostylidae was also investigated along the Vema Fracture Zone in an east-west direction as well as in the Puerto Rico Trench (Riehl et al., 2018). This study tested whether large bathymetric structures might serve as barriers to dispersal and, if so, whether this may potentially favor differentiation and eventually speciation. It could be demonstrated that some macrostylid species have wide geographic ranges extending more than $2000 \mathrm{~km}$ and in some cases across oceanic ridges and trench-abyss transitions (Bober et al., 2018a; Riehl et al., 2018). This finding supports the hypotheses that bathymetric gradients and mid-ocean ridges influence benthic communities and reduce dispersal. Both families, Macrostylidae and Haploniscidae, are poorly adapted to swimming - contrary to Munnopsidae (Bober et al., 2018b; Hessler, 1993; Hessler and Strömberg, 1989; Wilson et al., 1989) - and it is thus not surprising that they show similar patterns of distribution. Similar to what is presented here for hadal haploniscids, hadal endemic species are also rather uncommon in the isopod families Desmosomatidae, Macrostylidae, and Munnopsidae (Kniesz et al., 2018; Riehl et al., unpublished data).

Within the Amphipoda, another taxon of the Peracarida, the genus Rhachotropis S.I. Smith, 1883 has the widest horizontal and bathymetric distribution of all amphipod genera known worldwide and occurs with a high number of species both in the KKT and in the Sea of Okhotsk (Lörz et al., 2018). For example, the predatory species Rhachotropis saskia Lörz and Jazdzewska, 2018 was sampled in the hadal at both continental and ocean abyssal margins of the KKT as well as at hadal depths of the trench. This species occurs over a wide bathymetric distribution of over $3000 \mathrm{~m}$, with the data being confirmed by molecular analysis. It is thus likely that the KKT does not hamper the distribution of this species, as although Amphipoda are brooders as well, they are better swimmers than isopods. This result indicates the importance of analyses at species level for the understanding of the processes that drive species distribution patterns.

\subsection{Geo differences}

Out of the 21 identified morphospecies, eleven occurred in only one of the four geo zones ( $H$. aff. $H$. belyaevi B (ETA), $H$. aff. $H$. belyaevi E (SOO), H. cf. H. intermedius (WTA), H. sp. \#23 (CTH), H. sp. \#24 (CTH), H. sp. \#25 (ETA), H. vitjazi (CTH), M. sp. \#12 (ETA), M. sp. \#16 (CTH), M. sp. \#20 (ETA), and M. sp. \#26 (WTA)). However, five of them ( $H$. aff. $H$. belyaevi E, $H$. sp. \#24, H. vitjazi, M. sp. \#20, and M. sp. \#26) did not comprise of more than three individuals, which is why these findings are rather inconclusive due to sampling bias. Regarding the $H$. belyaevi complex, it is noteworthy that $H$. aff. $H$. belyaevi B only occurred east of the KKT, while $H$. aff. $H$. belyaevi D and E only occurred west of the trench, with $H$. aff. $H$. belyaevi D further dispersing into the SOO. Assuming the observed similarity between these species is due to a close phylogenetic relationship this may indicate differentiation of the two species from a common ancestor due to genetic isolation caused by the trench. However, this theory must be tested with genetic data. Furthermore, $H$. cf. $H$. intermedius was only found west of the trench, while the new morphospecies $H$. sp. \#25 and $M$. sp. \#12 were only detected east of the KKT. These biogeographic differences might indicate an isolating role of the KKT for the geographic distribution, as it was also revealed for the Ischnomesidae (Bober, 2019; Bober et al., this issue) and certain species of Macrostylidae (Bober et al., 2018c; Riehl et al., unpublished data). Cryptic speciation has been studied in several Southern Ocean isopod species. For example, molecular data revealed a highly diverse species flock within the munnopsid deep-sea isopod Betamorpha fusiformis (Barnard, 1920) and Ceratoserolis trilobitoides (Eights, 1833), as well as the giant Antarctic isopod Glyptonotus antarcticus Eights, 1852 (Held, 2003; Held and Wägele, 2005; Raupach et al., 2007). Further discoveries of Southern Ocean isopod species complexes in isopods over short geographic distances, similarly to the H. balyaevi complex, are for example the acanthaspidiid isopod Acanthaspidia drygalskii Vanhöffen, 1914 (Raupach and Wägele, 2006).
While cryptic speciation can occur in some areas, for example those driven by glaciation and warming, as illustrated by benthic isopod fauna from the waters around Patagonia and the Falkland Islands (Leese et al., 2008), there are also examples of long distance dispersal in the same lineages, for example in Septemserolis septemcarinata (Miers, 1875) as has been shown by Leese et al. (2010).

Remarkably, four species were present in all geo zones, except for the SOO ( $H$. aff. $H$. belyaevi C, $H$. gibbernasutus, $H$. hydroniscoides, and $M$. latus). This is especially interesting in the case of $H$. gibbernasutus, and $H$. hydroniscoides, as they were two of the dominant species in our samples and highly abundant in the other geo zones. These findings indicate a strong isolating effect of the Kuril Islands and the bathyal depths of the ridge. This is further underlined by the fact that not a single specimen of Haploniscidae was found at bathyal depth during the three expeditions mentioned here. Hence, the depth difference between the abyssal NW Pacific and the bathyal Kuril ridge might be an additional barrier that hinders dispersal of most haploniscid species, even though we could not test this depth effect in our study, due to the lack of individuals from bathyal depths. H. belyaevi is the only species reported from bathyal stations of the Vitjaz expeditions. For this reason, it is likely that this is also the only species of the Haploniscidae which might have been able to immigrate into the SOO, probably via either the Krusenstern or Bussol straits. The members of the identified complex comprised of $H$. belyaevi and five very similar species ( $H$. aff. $H$. belyaevi A-E) can be differentiated by their differing males. Similar to other such species complexes in haploniscids (Brökeland, 2010b, 2010a) the females are much more difficult to tell apart. This is likely the explanation for why $H$. aff. $H$. belyaevi $\mathrm{C}$ and $\mathrm{E}$ only comprise adult males. Both morphospecies share characteristics in the general body shape, antennae, and rostrum, however, they show distinct differences in the expression of anterolateral protrusions of the cephalothorax and posterolateral spines of the pleotelson. This theory, however, still needs to be tested using genetic approaches. The same applies to the morphospecies $H$. aff. $H$. belyaevi B and D, which only consist of adult females, which could be conspecific counterparts to $H$. aff. $H$. belyaevi $\mathrm{C}$ and E. Haploniscus aff. H. belyaevi A, however, may potentially constitute the manca stage of $H$. belyaevi, being generally smaller in size and showing a reduced expression of some of the distinct characteristics in the antennae, rostrum, and posterolateral spines of $H$. belyaevi. As $H$. belyaevi is the only known haploniscid species that is able to cross bathyal depths, we postulate that this species potentially invaded the SOO from the NW Pacific and may currently differentiate into two new species through restricted gene flow caused by the potential barriers, i.e. the KKT and the Kuril Islands. This hypothesis is supported by the fact that $H$. aff. $H$. belyaevi B, together with $H$. aff. $H$. belyaevi $\mathrm{C}$ were the only morphospecies from the $H$. belyaevi complex, which did not occur in the SOO, while $H$. aff. $H$. belyaevi D and $\mathrm{E}$ did not occur east of the KKT. The species $H$. belyaevi has not been recorded for the Sea of Okhotsk before. It is possible that $H$. belyaevi outcompetes $H$. hydroniscoides and $H$. gibbernasutus thus hindering their colonization of the Kuril Basin of the SOO (see e.g., Byers, 2009).

\section{Conclusion}

The isopod family Haploniscidae in the Northwest Pacific features species with a wide range of distribution sizes, both geographically and bathymetrically. Distributions range from local stations (if their rarity is not caused by sampling bias) to regional and while some species occur from upper abyssal to hadal depths, others are restricted to one of these depth zones. The KKT appears to isolate NW Pacific Haploniscidae from those of the Sea of Okhotsk, as well as those from the western and eastern abyssal margins of the KKT. Contrastingly to what was observed in the literature, hadal endemism in this study does not differ from that of abyssal depths, as many hadal species also report wider geographic and bathymetric ranges. 


\section{Declaration of Competing Interest}

We herewith declare that there is no conflict of interest for the authors.

\section{Acknowledgements}

The Haploniscidae were collected and sorted within the framework of several large international projects. The projects KuramBio I and II projects and the SokhoBio Project were funded by the PTJ (German Ministry for Science and Education), grant 03G0857A, KuramBio I BMBF grant 03G0223A, as well as KuramBio II BMBF grant 03G0250A to Prof. Dr. Angelika Brandt, University of Hamburg, now Senckenberg Museum, Frankfurt, Germany.

The projects were also supported by the Russian Foundation of Basis Research (projects 13-04-02144, 16-04-01431), the Council of the President of the Russian Federation (project MK-2599.2013.4), Russian Federation Government grant No 11. G34.31.0010, grant of Presidium of the Far East Branch of RAS (12-I-P30-07).

We thank the crews of the RVs Sonne and Akademik M.A. Lavrentyev for their help on board and all student helpers and technicians for support and help with the sorting of the extensive expedition material.

\section{References}

Anderson, M., Gorley, R.N., Clarke, R.K., 2008. Permanova + for Primer: guide to software and statistical methods.

Barnard, K.H., 1920. Contribution to the Crustacean fauna of South Africa No. 6 Further Additions to the list of marine Isopoda. Ann. South Afr. Mus. 17, 319-428.

Belyaev, G.M., 1989. Deep-Sea Ocean Trenches and their Fauna. Nauka Publishing Houese, USSR Academy of Sciences, P.P. Shirshov Institute of Oceanography, Moscow.

Belyaev, G.M., 1983. Investigation of ultraabyssal fauna, in: Research Vessel "Vitjaz" and Her Expeditions 1949-1979. Nauka Publishing Houese, USSR Academy of Sciences, P.P. Shirshov Institute of Oceanography, Moscow, pp. 258-267.

Birstein, J.A., 1971. Additions to the fauna of isopods (Crustacea, Isopoda) of the KurileKamchatka Trench. Part II. Asellota 2. In: Fauna of the Kurile-Kamchatka Trench and its environment based on data of the 39th Cruise of the R/V "Vityaz," Proceedings of the Institute of Oceanology. Academy of Sciences of the USSR, Moscow, pp. 162-238.

Birstein, J.A., 1970. New Crustacea Isopoda from the Kurile-Kamchatka Trench area. Part I. In: Bogorov, V.G. (Ed.), Fauna of the Kurile-Kamchatka Trench and its environment based on data of the 39th Cruise of the R/V "Vityaz," Proceedings of the Institute of Oceanology. Academy of Sciences of the USSR, Moscow356, pp. 308.

Birstein, J.A., 1963. Deep water isopods (Crustacea, Isopoda) of the north-western part of the Pacific Ocean. Proceedings of the Institute of Oceanology. Academy of Sciences of the USSR, Moscow.

Bober, J., 2019. Diversität der Ischnomesidae (Peracarida: Amphipoda) des Nordwest Pazifik. Masters Thesis. University of Hamburg, Hamburg, Germany.

Bober, J., Brandt, A., Frutos, I., Schwentner, M., this issue. Diversity and distribution of Ischnomesidae (Crustacea: Isopoda: Asellota) in the Northwest Pacific Ocean along the Kuril-Kamchatka Trench - a genetic perspective. Prog. Oceanogr. 178, 102174. https://doi.org/10.1016/j.pocean.2019.102174.

Bober, S., Brix, S., Riehl, T., Schwentner, M., Brandt, A., 2018a. Does the Mid-Atlantic Ridge affect the distribution of abyssal benthic crustaceans across the Atlantic Ocean? Deep-Sea Res. Part II Top. Stud. Oceanogr. 148, 91-104. https://doi.org/10.1016/j. dsr2.2018.02.007.

Bober, S., Riehl, T., Brandt, A., 2018b. An organ of equilibrium in deep-sea isopods revealed: the statocyst of Macrostylidae (Crustacea, Peracarida, Janiroidea). Zoomorphology 137, 71-82. https://doi.org/10.1007/s00435-017-0376-5.

Bober, S., Riehl, T., Henne, S., Brandt, A., 2018c. New Macrostylidae (Isopoda) from the Northwest Pacific Basin described by means of integrative taxonomy with reference to geographical barriers in the abyss. Zool. J. Linn. Soc. 182, 549-603. https://doi. org/10.1093/zoolinnean/zlx042.

Bowen, B.W., Rocha, L.A., Toonen, R.J., Karl, S.A., 2013. The origins of tropical marine biodiversity. Trends Ecol. Evol. 28, 359-366. https://doi.org/10.1016/j.tree.2013. 01.018.

Brandt, A., Brix, S., Riehl, T., Malyutina, M.V., this issue. Biodiversity and biogeography of the abyssal and hadal Kuril-Kamchatka Trench and adjacent NW Pacific deep-sea regions. Prog. Oceanogr.

Brandt, A., Elsner, N., Brenke, N., Golovan, O., Malyutina, M.V., Riehl, T., Schwabe, E., Würzberg, L., 2013. Epifauna of the Sea of Japan collected via a new epibenthic sledge equipped with camera and environmental sensor systems. Deep Sea Res. Part II Top. Stud. Oceanogr. 86-87, 43-55. https://doi.org/10.1016/j.dsr2.2012.07.039.

Brandt, A., Griffiths, H., Gutt, J., Linse, K., Schiaparelli, S., Ballerini, T., Danis, B., Pfannkuche, O., 2014. Challenges of deep-sea biodiversity assessments in the Southern Ocean. Adv, Polar Sci. 25, 204-212.

Brandt, A., Malyutina, M.V., 2012. The German-Russian deep-sea expedition KuramBio (Kurile Kamchatka Biodiversity Study) : to the Kurile Kamchatka Trench and abyssal plain on board of the R/V Sonne, 223rd Expedition, July 21th - September 7th 2012 (Cruise Report), R/V Sonne Cruise Reports. University of Hamburg; Biozentrum Grindel \& Zoologisches Museum Hamburg, Hamburg.

Brandt, A., shipboard scientific party, 2016. Kuril Kamchatka Biodiversity Studies II - RV Sonne SO250, Tomakomai-Yokohama (Japan), 16.08.-26.09.2016 (Cruise report). University of Hamburg, Hamburg, Germany.

Brenke, N., 2005. An epibenthic sledge for operations on marine soft bottom and bedrock. Mar. Technol. Soc. J. 39, 10-21. https://doi.org/10.4031/002533205787444015.

Brix, S., Leese, F., Riehl, T., Kihara, T.C., 2015. A new genus and new species of Desmosomatidae Sars, 1897 (Isopoda) from the eastern South Atlantic abyss described by means of integrative taxonomy. Mar. Biodivers. 45, 7-61. https://doi.org/ 10.1007/s12526-014-0218-3.

Brökeland, W., 2010a. Description of four new species from the Haploniscus unicornis Menzies, 1956 complex (Isopoda: Asellota: Haploniscidae). Zootaxa 2536, 1-35.

Brökeland, W., 2010b. Redescription of Haploniscus rostratus (Menzies, 1962) (Crustacea: Peracarida: Isopoda) with observations on the postmarsupial development, size ranges and distribution. Zootaxa 2521, 1-25.

Brökeland, W., Raupach, M.J., 2008. A species complex within the isopod genus Haploniscus (Crustacea: Malacostraca: Peracarida) from the Southern Ocean deep sea: a morphological and molecular approach. Zool. J. Linn. Soc. 152, 655-706. https:// doi.org/10.1111/j.1096-3642.2008.00362.x.

Brown, A., Thatje, S., 2013. Explaining bathymetric diversity patterns in marine benthic invertebrates and demersal fishes: physiological contributions to adaptation of life at depth. Biol. Rev. 89, 406-426. https://doi.org/10.1111/brv.12061.

Butlin, R., Debelle, A., Kerth, C., Snook, R.R., Beukeboom, L.W., et al., 2012. What do we need to know about speciation? Trends Ecol. Evol. 27, 27-39. https://doi.org/10. 1016/j.tree.2011.09.002

Byers, J.E., 2009. Competition in marine invasions. In: Rilov, G., Crooks, J.A. (Eds.), Biological Invasions in Marine Ecosystems, Ecological Studies. Springer, Berlin, pp. 245-260.

Chaudhary, C., Saeedi, H., Costello, M.J., 2017. Marine species richness is bimodal with latitude: a reply to Fernandez and Marques. Trends Ecol. Evol. 32, 234-237. https:// doi.org/10.1016/j.tree.2017.02.007.

Clarke, K.R., Gorley, R.N., 2006. PRIMER v6 user manual/tutorial. PRIMER-E Ltd, Plymouth, UK.

Dreutter, S., Steffen, M., Martinez Arbizu, P., Brandt, A., this issue. The "top five" deepest trenches lost one of its members. Prog. Oceanogr.

Eights, J., 1852. Description of a new animal belonging to the Crustacea, discovered in the Antarctic seas by the author. Trans. Albany Inst. 2, 331-334.

Eights, J., 1833. Description of a new crustaceous animal found on the shores of the South Shetland Islands, with remarks on their natural history. Trans. Albany Inst. 2, 53-69.

Elsner, N.O., Malyutina, M.V., Golovan, O.A., Brenke, N., Riehl, T., Brandt, A., 2015. Deep down: Isopod biodiversity of the Kuril-Kamchatka abyssal area including a comparison with data of previous expeditions of the RV Vityaz. Deep Sea Res. Part II Top. Stud. Oceanogr., The German-Russian deep-sea expedition KuramBio (Kurile Kamchatka Biodiversity Studies) on board of the RV Sonne in 2012 following the footsteps of the legendary expeditions with RV Vityaz 111, 210-219. https://doi.org/ $10.1016 /$ j.dsr2.2014.08.007.

Etter, R.J., Mullineaux, L.S., 2001. Deep-sea communities. In: Marine Community Ecology. Sinauer Associates Inc, Sunderland, pp. 367-393.

Forbes, E., 1859. The natural history of the European seas, Outlines of the natural history of Europe. John van Voorst, Paternoster Row., London.

France, S.C., Kocher, T.D., 1996. Geographic and bathymetric patterns of mitochondrial 16S rRNA sequence divergence among deep-sea amphipods, Eurythenes gryllus. Mar. Biol. 126, 633-643. https://doi.org/10.1007/BF00351330.

Golovan, O.A., Błażewicz, M., Brandt, A., Jażdżewska, A.M., Jóźwiak, P., Lavrenteva, A.V., Malyutina, M.V., Petryashov, V.V., Riehl, T., Sattarova, V.V., 2019. Diversity and distribution of peracarid crustaceans (Malacostraca) from the abyss adjacent to the Kuril-Kamchatka Trench. Mar. Biodivers. 49, 1343-1360. https://doi.org/10. 1007/s12526-018-0908-3.

Hansen, H.J., 1916a. Crustacea Malacostraca: the order Isopoda. Dan. Ingolf Exped. 3, $1-262$.

Hansen, H.J., 1916. Crustacea malacostraca: the order isopoda. Dan. Ingolf Exped. 3.

Hausdorf, B., 2011. Progress toward a general species concept. Evolution 65, 923-931. https://doi.org/10.1111/j.1558-5646.2011.01231.x.

Havermans, C., Sonet, G., d'Udekem d'Acoz, C., Nagy, Z.T., Martin, P., Brix, S., Riehl, T., Agrawal, S., Held, C., 2013. Genetic and morphological divergences in the cosmopolitan deep-sea amphipod Eurythenes gryllus reveal a diverse abyss and a bipolar species. PLoS ONE 8, e74218. https://doi.org/10.1371/journal.pone.0074218.

Held, C., 2003. Molecular evidence for cryptic speciation within the widespread Antarctic crustacean Ceratoserolis trilobitoides (Crustacea, Isopoda). In: Huiskes, A.H., Gieskes, W.W., Rozema, J., Schorno, R.M., van der Vies, S.M., Wolff, W.J. (Eds.), Antarctic Biology in a Global Context. Backhuys Publishers, Leiden, pp. 135-139.

Held, C., Wägele, J.-W., 2005. Cryptic speciation in the giant Antarctic isopod Glyptonotus antarcticus (Isopoda: Valvifera: Chaetiliidae). Sci. Mar. 69, 175-181. https://doi.org/ 10.3989/scimar.2005.69s2175.

Hessler, R.R., 1993. Swimming morphology in Eurycope cornuta (Isopoda, Asellota). J. Crustac. Biol. 13, 667-674. https://doi.org/10.1163/193724093X00237.

Hessler, R.R., Sanders, H.L., 1967. Faunal diversity in the deep-sea. Deep Sea Res. Oceanogr. Abstr. 14, 65-78. https://doi.org/10.1016/0011-7471(67)90029-0.

Hessler, R.R., Strömberg, J.O., 1989. Behavior of janiroidean isopods (Asellota), with special reference to deep sea genera. Sarsia 74, 145-159.

Jamieson, A., 2015. The Hadal Zone: Life in the Deepest Oceans. Cambridge University Press, Cambridge.

Jamieson, A.J., Fujii, T., Mayor, D.J., Solan, M., Priede, I.G., 2010. Hadal trenches: the ecology of the deepest places on Earth. Trends Ecol. Evol. 25, 190-197. https://doi. 
org/10.1016/j.tree.2009.09.009.

Klaeschen, D., Belykh, I., Gnibidenko, H., Patrikeyev, S., von Huene, R., 1994. Structure of the Kuril Trench from seismic reflection records. J. Geophys. Res. 99.

Kniesz, K., Brandt, A., Riehl, T., 2018. Peritrich ciliate epibionts on the new hadal isopod species Macrostylis marionae from the Puerto Rico Trench as an indicator for sexspecific behaviour. Deep-Sea Res. Part II Top. Stud. Oceanogr. 148, 105-129. https:// doi.org/10.1016/j.dsr2.2017.10.007.

Kussakin, O.G., 2004. Biota of the Russian waters of the Sea of Japan, Vol.1 Crustacea (Cladocera, Leptostraca, Mysidacea, Euphausiacea) and Pycnogonida. Dalnauka, Vladivostok, Russia.

Kussakin, O.G., 1999. Marine and brackish-water isopods from cold and temperate waters of the Northern Hemisphere Suborder Asellota. Part 2. Families Joeropsididae, Nannoniscidae, Desmosomatidae, Macrostylidae., Keys to the Fauna of the SSSR. Publication of the Zoological Institute of the Russian Academy of Sciences, St. Petersburg.

Kussakin, O.G., 1988. Marine and brackish-water Crustacea (Isopoda) of cold and temperate waters of the Northern Hemisphere. 3. Suborder Asellota 1. Janiridae, Santiidae, Dendrotionidae, Munnidae, Haplomunnidae, Mesosignidae, Haploniscidae, Mictosomatidae, Ischnomesidae, Keys to the Fauna of the SSSR Academy of Sciences of the USSR, Leningrad.

Kussakin, O.G., 1982. Marine and brackish-water Crustacea (Isopoda) of cold and temperate waters of the Northern Hemisphere. Anthuridea, Microcerberidea, Valvifera, Tyloidea, Opredeliteli po Faune SSR. Akademiya Nauk, SSSR, Leningrad.

Kussakin, O.G., 1979. On the fauna of isopod crustaceans (Crustacea, Isopoda) of the Sea of Okhotsk, in: Studies of pelagic and bottom organisms of Far Eastern Seas. Vladivostok, pp. 106-122.

Kussakin, O.G., 1971. Additions to the fauna of isopods (Crustacea, Isopoda) of the KurileKamchatka Trench. Part III. Flabellifera and Valvifera. In: Fauna of the KurileKamchatka Trench and its environment based on data of the 39th Cruise of the R/V "Vityaz," Proceedings of the Institute of Oceanology. Academy of Sciences of the USSR, Moscow, pp. 239-273.

Kussakin, O.G., 1965. On the fauna of the Desmosomatidae (Crustacea, Isopoda) of the Far-Eastern seas of the USSR. Issled. Dalnevostocnya Morej SSSR Explor. Far-East. Seas USSR 3, 115-144.

Kussakin, O.G., Vasina, G.S., 1990. Isopod crustaceans of the suborders Flabellifera and Valvifera from the bathyal region of the Kurile Islands. In: Systematics and Chorology of Marine Organisms. Institute of Marine Biology, Far Eastern branch of the Academy of Sciences of the USSR, Vladivostok, Russia, pp. 43-63.

Leese, F., Agrawal, S., Held, C., 2010. Long-distance island hopping without dispersal stages: transportation across major zoogeographic barriers in a Southern Ocean isopod. Naturwissenschaften 97, 583-594. https://doi.org/10.1007/s00114-0100674-y.

Leese, F., Kop, A., Wägele, J.-W., Held, C., 2008. Cryptic speciation in a benthic isopod from Patagonian and Falkland Island waters and the impact of glaciations on its population structure. Front. Zool. 5, 1-15. https://doi.org/10.1186/1742-9994-5-19.

Lichtenstein, H., 1822. §. 30 [Crustacea], in: Mand, M.G. (Ed.), Observationes in historiam naturalem et anatomiam comparatam in itinere Groenlandico factae. Dissertatio in auguralis quam consensu et auctoritate gratiosi medicorum ordinis in universitate literaria berolinensi ut summi in medicina et chirurgia honores rite sibi concedantur die XXII. M. Iulii A. MDCCCXXII H.L.Q.S., publice defendet auctor Martinus Gulielmus Mandt Beyenburgensis. Opponentibus: J.Th. v. Brandt Med. Cd., J. Ollenroth Med. Cd., E. Gabler Med. Cd. Formis Brueschckianis, Berlin, pp. 31-37.

Lincoln, R.J., 1985. Deep-sea asellote isopods of the north-east Atlantic: the family Haploniscidae. J. Nat. Hist. 19, 655-695. https://doi.org/10.1080/ 00222938500770411.

Lörz, A.-N., Jażdżewska, A.M., Brandt, A., 2018. A new predator connecting the abyssal with the hadal in the Kuril-Kamchatka Trench, NW Pacific. PeerJ 6, e4887. https:// doi.org/10.7717/peerj. 4887.

Malyutina, M.V., Brandt, A., Ivin, V.V., 2015. The Russian-German deep-sea expedition SokhoBio (Sea of Okhotsk Biodiversity Studies) to the Kurile Basin of the Sea of Okhotsk on board of the R/V Akademik M.A. Lavrentyev (Cruise Report). A.V. Zhirmunsky's Institute of Marine Biology, FEB RAS, Vladivostok, Russia.

McClain, C.R., Allen, A.P., Tittensor, D.P., Rex, M.A., 2012. Energetics of life on the deep seafloor. Proc. Natl. Acad. Sci. 109, 15366-15371.

Menzies, R.J., 1962. The isopods of abyssal depths in the Atlantic Ocean. In: Barnard, J.L., Menzies, R.J., Bacescu, M.C. (Eds.), Abyssal Crustacea, Vema Research Series. Columbia University Press, New York, pp. 79-206.

Miers, E.J., 1875. Descriptions of three additional species of Crustacea from Kerguelen's land and Crozet Island, with remarks upon the genus Paramoera. Ann. Mag. Nat. Hist. $16,115-118$.

Nosil, P., 2012. Ecological speciation, Oxford series in ecology and evolution. Oxford University Press, Oxford; New York.

Ramirez-Llodra, E., Brandt, A., Danovaro, R., De Mol, B., Escobar, E., German, C.R., Levin, L.A., Martinez Arbizu, P., Menot, L., Buhl-Mortensen, P., Narayanaswamy, B.E., Smith, C.R., Tittensor, D.P., Tyler, P.A., Vanreusel, A., Vecchione, M., 2010. Deep, diverse and definitely different: unique attributes of the world's largest ecosystem. Biogeosciences 7, 2851-2899. https://doi.org/10.5194/bg-7-2851-2010.

Raupach, M.J., Malyutina, M.V., Brandt, A., Wägele, J.-W., 2007. Molecular data reveal a highly diverse species flock within the munnopsoid deep-sea isopod Betamorpha fusiformis (Barnard, 1920) (Crustacea: Isopoda: Asellota) in the Southern Ocean. Deep Sea Res. Part II Top. Stud. Oceanogr. 54, 1820-1830. https://doi.org/10.1016/j.dsr2. 2007.07.009.

Raupach, M.J., Wägele, J.-W., 2006. Distinguishing cryptic species in Antarctic Asellota (Crustacea:Isopoda) - a preliminary study of mitochondrial DNA in Acanthaspidia drygalskii. Antarctic Science. https://doi.org/10.1017/S0954102006000228.

Rex, M.A., McClain, C.R., Johnson, N.A., Etter, R.J., Allen, J.A., Bouchet, P., Warén, A., 2005. A source-sink hypothesis for abyssal biodiversity. Am. Nat. 165, 163-178.

Richardson, H., 1908a. Some new Isopoda of the superfamily Aselloidea from the Atlantic coast of North America. Proc. U. S. Natl. Mus. 35, 71-86.

Richardson, H., 1908b. Some new Isopoda of the superfamily Aselloidea from the Atlantic coast of North America. Smithson. Inst. Press.

Riehl, T., Brenke, N., Brix, S., Driskell, A., Kaiser, S., Brandt, A., 2014. Field and laboratory methods for DNA studies on deep-sea isopod crustaceans. Pol. Polar Res. 35, 205-226. https://doi.org/10.2478/popore-2014-0018.

Riehl, T., Golovan, O.A., Malyutina, M.V., unpublished data. Isopoda. In: Saeedi, H., Brandt, A. (Eds.), Biogeographic Atlas of the Deep NW Pacific Fauna. Pensoft.

Riehl, T., Kühn, M.A.L., this issue. Uniting what belongs together - reevaluation of the isopod species Macrostylis grandis and M. ovata using ontogenetic, morphological and genetic evidence. Prog. Oceanogr.

Riehl, T., Lins, L., Brandt, A., 2018. The effects of depth, distance, and the Mid-Atlantic Ridge on genetic differentiation of abyssal and hadal isopods (Macrostylidae). Deep Sea Res. Part II Top. Stud. Oceanogr. 148, 74-90. https://doi.org/10.1016/j.dsr2. 2017.10.005.

Sanders, H.L., 1968. Marine benthic diversity: a comparative study. Am. Nat. 102, 243-282.

Schnurr, S., Osborn, K.J., Malyutina, M., Jennings, R., Brix, S., Driskell, A., Svavarsson, J., Martínez Arbizu, P., 2018. Hidden diversity in two species complexes of munnopsid isopods (Crustacea) at the transition between the northernmost North Atlantic and the Nordic Seas. Mar. Biodivers. 48, 813-843. https://doi.org/10.1007/s12526-018 0877-6.

Skarlato, O.A., 1974. Bivalvia of the temporary waters of the western part of the Pacific Ocean. Academy of Sciences of the USSR, Leningrad.

Smith, S.I., 1883. Review of the marine Crustacea of Labrador. Proc. U. S. Natl. Mus. 6 , 223-232.

Snelgrove, P.V.R., Smith, C.R., 2002. A riot of species in an environmental calm: the paradox of the species-rich deep-sea floor. Oceanogr. Mar. Biol. Annu. Rev. 40, 311-342.

Sobel, J.M., Chen, G.F., Watt, L.R., Schemske, D.W., 2010. The biology of speciation. Evolution 64, 295-315. https://doi.org/10.1111/j.1558-5646.2009.00877.x.

Stuart, C.T., Rex, M.A., Etter, R.J., 2003. Large-scale spatial and temporal patterns of deep-sea benthic species diversity. In: Tyler, P.A. (Ed.), Ecosystems of the Deep Oceans, Ecosystems of the World. Elsevier, Amsterdam.

Tyler, P.A., 2002. Deep-sea eukaryote ecology of the semi-isolated basins off Japan. J. Oceanogr. 58, 333-341. https://doi.org/10.1023/A:1015817910449.

Uehara, K., Miyake, H., 1999. Deep flows on the slope inshore of the Kuril-Kamchatka Trench southeast off Cape Erimo, Hokkaido. J. Oceanogr. 55, 559-573. https://doi. org/10.1023/A:1007828517317.

Ushakov, P.V., 1953. The Fauna of the Sea of Okhotsk and Conditions of Life in it. Academy of Sciences of USSR Press, Leningrad.

Ushakov, P.V., 1952. Chukchy Sea and its bottom fauna. In: Far North-East of USSR. Academy of Sciences of the USSR, Moscow, pp. 80-97.

Vanhöffen, E., 1914. Die Isopoden der Deutschen Südpolar-Expedition 1901-1903. In: von Drygalsky, E. (Ed.), Deutsche Südpolarexpedition 1901-1903, Zoologie. Georg Reimer, Berlin, pp. 449-598.

Watling, L., Guinotte, J., Clark, M.R., Smith, C.R., 2013. A proposed biogeography of the deep ocean floor. Prog. Oceanogr. 111, 91-112. https://doi.org/10.1016/j.pocean. 2012.11.003.

Wilson, G.D.F., 1982. Systematics of a species complex in the deep-sea genus Eurycope, with a revision of six previously described species (Crustacea, Isopoda, Eurycopidae), Bulletin of the Scripps Institution of Oceanography. University of California Press, Berkley, Los Angeles, London.

Wilson, G.D.F., Boudrias, M.A., Miller, R., Harbison, G.R., 1989. An unique form of swimming in the deep-sea isopod genus Munneurycope: walking. Am. Zool. 29,66A.

Wilson, G.D.F., Hessler, R.R., 1987. Speciation in the deep sea. Annu. Rev. Ecol. Syst. 18, 185-207.

Woolley, S.N.C., Tittensor, D.P., Dunstan, P.K., Guillera-Arroita, G., Lahoz-Monfort, J.J., Wintle, B.A., Worm, B., O'Hara, T.D., 2016. Deep-sea diversity patterns are shaped by energy availability. Nature 533, 393-396. https://doi.org/10.1038/nature17937.

Yasuhara, M., Hunt, G., Cronin, T.M., Hokanishi, N., Kawahata, H., Tsujimoto, A., Ishitake, M., 2012. Climatic forcing of Quaternary deep-sea benthic communities in the North Pacific Ocean. Paleobiology 38, 162-179. https://doi.org/10.1017/ S0094837300000464.

Zardus, J.D., Etter, R.J., Chase, M.R., Rex, M.A., Boyle, E.E., 2006. Bathymetric and geographic population structure in the pan-Atlantic deep-sea bivalve Deminucula atacellana (Schenck, 1939): Genetic structure in a deep-sea bivalve. Mol. Ecol. 15, 639-651. https://doi.org/10.1111/j.1365-294X.2005.02832.x. 